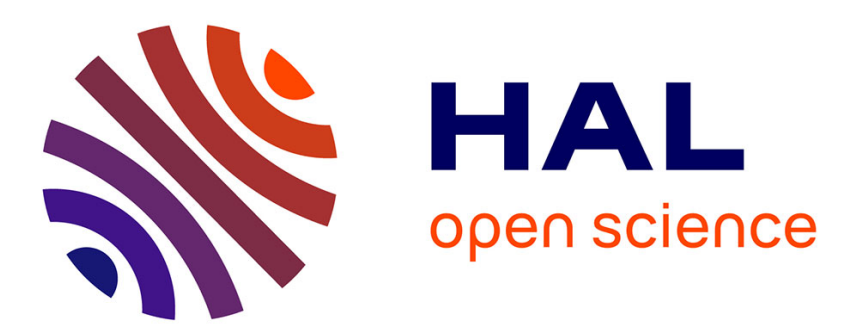

\title{
Reduction Kinetics of La2Mo2O9 and Phase Evolution during Reduction and Reoxidation
}

Gaëtan Buvat, Houssem Sellemi, Uday Ravella, Maud Barré, Sandrine Coste, Gwenaël Corbel, P. Lacorre

\section{- To cite this version:}

Gaëtan Buvat, Houssem Sellemi, Uday Ravella, Maud Barré, Sandrine Coste, et al.. Reduction Kinetics of La2Mo2O9 and Phase Evolution during Reduction and Reoxidation. Inorganic Chemistry, 2016, 55 (5), pp.2522-2533. 10.1021/acs.inorgchem.5b02876 . hal-01723564

\section{HAL Id: hal-01723564 https://hal.science/hal-01723564}

Submitted on 24 Jul 2019

HAL is a multi-disciplinary open access archive for the deposit and dissemination of scientific research documents, whether they are published or not. The documents may come from teaching and research institutions in France or abroad, or from public or private research centers.
L'archive ouverte pluridisciplinaire HAL, est destinée au dépôt et à la diffusion de documents scientifiques de niveau recherche, publiés ou non, émanant des établissements d'enseignement et de recherche français ou étrangers, des laboratoires publics ou privés. 


\title{
Reduction kinetics of $\mathrm{La}_{2} \mathrm{Mo}_{2} \mathrm{O}_{9}$ and phase evolution during reduction and re-oxidation
}

\author{
Gaëtan Buvat, ${ }^{\grave{y}}$ Houssem Sellemi, ${ }^{\grave{A} \S}$ Uday K. Ravella, ${ }^{\grave{A}}$ Maud Barré, ${ }^{\grave{A}}$ Sandrine Coste, ${ }^{\grave{A}}$ Gwenaël Corbel, ${ }^{\grave{A}}$ \\ Philippe Lacorre ${ }^{*} \dot{A}$
}

À Institut des Molécules et Matériaux du Mans (IMMM), Univ. Bretagne-Loire, UMR CNRS 6283, Univ. Maine, avenue Olivier Messiaen, 72085 Le Mans cedex 9, France

${ }^{\ddot{y}}$ Institut des Matériaux Jean Rouxel (IMN), Univ. Bretagne-Loire, UMR CNRS 6502, Univ. Nantes, 2 rue de la Houssinière, 44322 Nantes cedex 3, France

${ }^{\S}$ Unité de Recherche Synthèse et Structure de Nanomatériaux UR11ES30, Faculté des Sciences de Bizerte, Université de Carthage, 7021 Jarzouna, Tunisie

\begin{abstract} air, the reduced compounds are reoxidized while remaining amorphous. The annealing for $60 \mathrm{~h}$ at 350 degrees $\mathrm{C}$ in air of reduced $\mathrm{La}_{2} \mathrm{Mo}_{2} \mathrm{O}_{6.66}$, obtained beforehand by solid state reaction, gives an amorphous phase with composition $\mathrm{La}_{2} \mathrm{Mo}_{2} \mathrm{O}_{8.85}$. The existence domain of the reduced amorphous phase in terms of oxygen content therefore ranges at least from $\mathrm{O}_{6.2}$ to $\mathrm{O}_{8.85}$, thus including the composition $\mathrm{La}_{2} \mathrm{Mo}_{2} \mathrm{O}_{8.50}$ of the amorphous surface layer at the origin of a huge increase of ionic conductivity recently reported in nanowires of $\mathrm{La}_{2} \mathrm{Mo}_{2} \mathrm{O}_{9}$.
\end{abstract}

An amorphous reduced form of oxide ion conductor $\mathrm{La}_{2} \mathrm{Mo}_{2} \mathrm{O}_{9}$ had been proposed as sulfur-tolerant anode material for solid oxide fuel cell, but its oxygen content was not known. In this paper, we investigate the reduction kinetics by diluted hydrogen of $\mathrm{La}_{2} \mathrm{Mo}_{2} \mathrm{O}_{9}$ to amorphous, and the oxygen range of the amorphous form. The reduction kinetics is studied as a function of the powder specific surface area and of the temperature, on powders synthesized by solid state reaction and by polyol process using two different solvents. The reduction process was carried out by TGA under $10 \%$ $\mathrm{H}-2$ diluted in argon, and its kinetics is analyzed and modeled. As expected, small particles and high temperature lead to higher reduction rates. Several reduction steps were identified by XRD during the process. At $700^{\circ} \mathrm{C}^{2} a_{2} \mathrm{Mo}_{2} \mathrm{O}_{9}$ is directly reduced into the amorphous phase $\mathrm{La}_{2} \mathrm{Mo}_{2} \mathrm{O}_{7-y}$, whereas at $760^{\circ} \mathrm{C}$ reduction occurs through an intermediate crystallized $\mathrm{La}_{7} \mathrm{Mo}_{7} \mathrm{O}_{30}$ congruent to $\mathrm{La}_{2} \mathrm{Mo}_{2} \mathrm{O}_{8.57}$ ) phase before amorphization. In both cases, further reduction of $\mathrm{La}_{2} \mathrm{Mo}_{2} \mathrm{O}_{6.2}$ amorphous phase leads to an exsolution of metallic molybdenum and a molybdenum deficiency in the amorphous phase. Reoxidation of amorphous $\mathrm{La}_{2} \mathrm{Mo}_{2} \mathrm{O}_{7-\mathrm{y}}$ was studied by TGA, DTA and XRD. At low temperature in

KEYWORDS: $\mathrm{La}_{2} \mathrm{Mo}_{2} \mathrm{O}_{9}$, amorphous oxide, reduction kinetics, hydrogen reduction, thermogravimetric analysis, exsolution

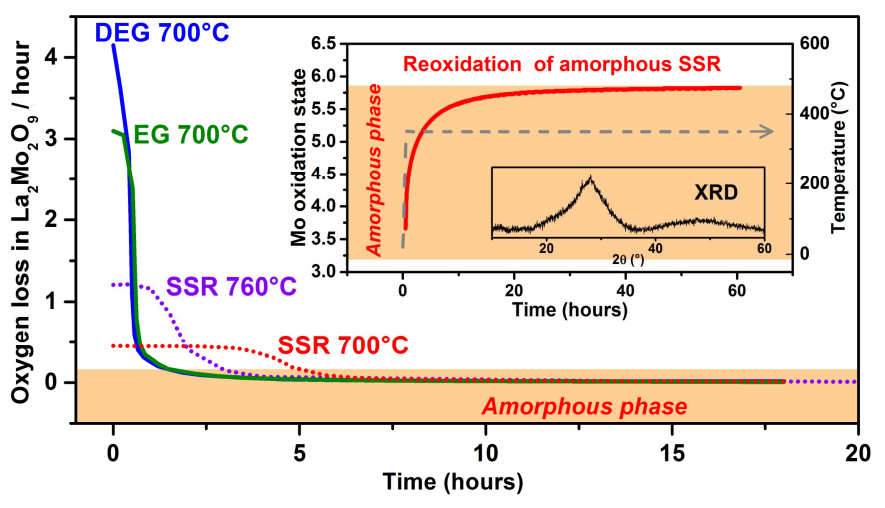

\section{INTRODUCTION}

Regarding the ecological issue for clean energy, a solid oxide fuel cell (SOFC) already appears as a very promising device. Fed at the anode by hydrogen, it releases only water while offering high efficiency. Among the numerous research works undertaken in order to improve the efficiency, stability, and lifetime of such cells, the anode improvement represents a crucial point in the development of SOFC because of the interplay between anode material and fuel gas. ${ }^{1}$ Currently, in conventional pure $\mathrm{H}_{2}$-fueled SOFC, the anode material most often consists in nickel-based composite such as Ni-YSZ cermet. However, studies showed that when appropriate materials are used SOFC could operate under different fuel gas such as hydrocarbons or hydrogen from natural gas reforming. ${ }^{2}$ Indeed, a few parts per million (ppm) of hydrogen sulfide present in this kind of fuel was shown to have a poisoning impact, decreasing the electrical performance of the Ni-based composite anode material. ${ }^{3}$ Alternatively, the decrease of operating temperature down to $700{ }^{\circ} \mathrm{C}$, at which electrocatalytic performance is lowered, implies the search for new anode materials.

Sixteen years ago, the fast oxide-ion conductivity of lanthanum molybdate $\mathrm{La}_{2} \mathrm{Mo}_{2} \mathrm{O}_{9}\left(5 \times 10^{-2} \mathrm{~S} \cdot \mathrm{cm}^{-1}\right.$ at $\left.700{ }^{\circ} \mathrm{C}\right)$ was discovered. ${ }^{4}$ This compound undergoes a reversible structural phase transition at around $580^{\circ} \mathrm{C}$, from a monoclinic $\alpha$ form at low temperature to a highly conducting and disordered $\beta$ cubic form at higher temperature. ${ }^{5}$ However, the reducibility of molybdenum restrains drastically the application of this oxidized phase as an electrolyte in conventional double-chamber SOFC: its decomposition under diluted $\mathrm{H}_{2}$ has already been reported in the literature. ${ }^{5-8}$ Even $\mathrm{Mo}^{6+}$ substitution by $\mathrm{W}^{6+}$, while slowing down the process, does not prevent reducibility.' Thus, slight reduction of $\mathrm{La}_{2} \mathrm{Mo}_{2} \mathrm{O}_{9}$ generates n-type electronic conductivity, leading to a mixed ionic-electronic conductor (MIEC), 
potentially interesting as anode material in conventional doublechamber SOFC. ${ }^{10}$ Further reduction produces an amorphous compound hereafter called $\mathrm{La}_{2} \mathrm{Mo}_{2} \mathrm{O}_{7-y}$. The amorphous reduced phase was successfully tested as a sulfur-tolerant anode material for SOFC. ${ }^{11}$

Therefore, so far, the most promising applications of $\mathrm{La}_{2} \mathrm{Mo}_{2} \mathrm{O}_{9}$-derived materials in SOFC devices are either for oxidized forms as electrolyte in single-chamber devices ${ }^{12}$ (with less stringent reducing conditions) or for reduced amorphous form as anode material in double-chamber devices. ${ }^{11,13}$ Very recently, Liu et al. ${ }^{14}$ showed that $\mathrm{La}_{2} \mathrm{Mo}_{2} \mathrm{O}_{9}$ nanowires prepared by electrospinning exhibit a 3 orders of magnitude increase of ionic conductivity with respect to the bulk material. They attribute most of this increase to the presence of a highly conducting surface layer of strained amorphous phase with composition $\mathrm{La}_{2} \mathrm{Mo}_{2} \mathrm{O}_{8.5}$ around the nanowires. If confirmed, such a huge ionic conductivity would bolster research and development on such materials, among which partially reduced amorphous forms of the lanthanum molybdate. From a fundamental point of view, a better understanding of the stability and existence ranges of these amorphous phases is highly desirable as well as of their basic properties.

Previous reports already described $\mathrm{La}_{2} \mathrm{Mo}_{2} \mathrm{O}_{9}$ reduction into amorphous phase. ${ }^{15,16}$ Vega Castillo et al. obtained the amorphous compound $\mathrm{La}_{2} \mathrm{Mo}_{2} \mathrm{O}_{6.88}$ from a pellet after $80 \mathrm{~h}$ of reduction at $608{ }^{\circ} \mathrm{C}$ under $10 \% \mathrm{H}_{2} / \mathrm{Ar}$ atmosphere with a flow rate of $6 \mathrm{~L} \cdot \mathrm{h}^{-1}$. $^{8}$ However, above $900{ }^{\circ} \mathrm{C}$, the amorphous phase undergoes a slight crystallization, and at $1000{ }^{\circ} \mathrm{C}$ under a partial oxygen pressure $\left(\mathrm{pO}_{2}\right)$ below $10^{-10} \mathrm{~Pa}$, the reduction leads to mixtures of crystallized molybdates. The same authors investigated the thermodynamics of the reduction process by studying the phase stability at different temperatures in a wide range of partial oxygen pressures ${ }^{8,10}$ (see Figure 1). Thus, at 718

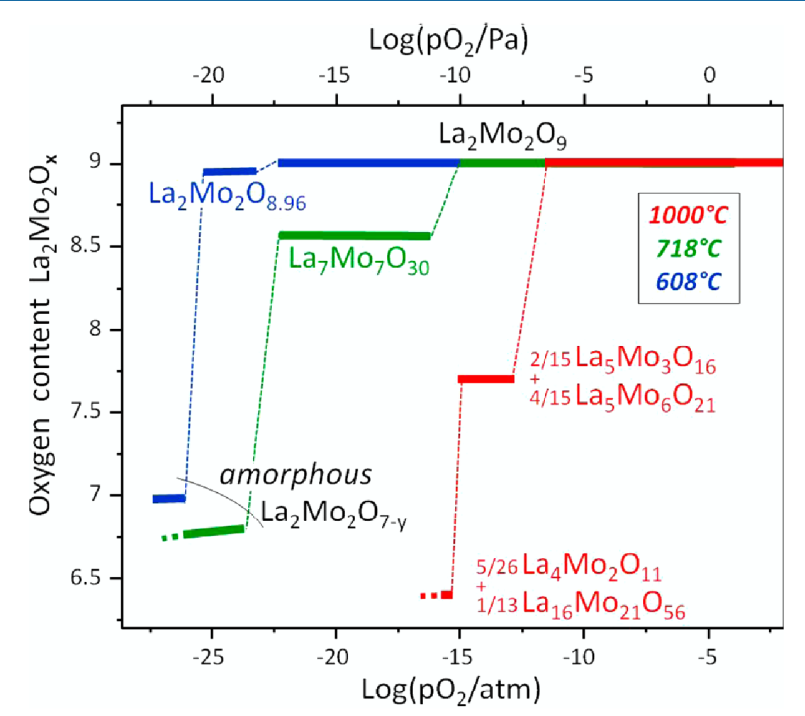

Figure 1. Thermodynamic stability of $\mathrm{La}_{2} \mathrm{Mo}_{2} \mathrm{O}_{9}$ and reduced forms under low oxygen pressure at 608 (blue), 718 (green), and $1000{ }^{\circ} \mathrm{C}$ (red) (adapted from refs 8 and 10).

${ }^{\circ} \mathrm{C}$, amorphous $\mathrm{La}_{2} \mathrm{Mo}_{2} \mathrm{O}_{7-y}$ phase appears below $\mathrm{pO}_{2}=10^{-17}$ $\mathrm{Pa}$. At $608^{\circ} \mathrm{C}$, the slightly reduced and crystallized MIEC phase $\mathrm{La}_{2} \mathrm{Mo}_{2} \mathrm{O}_{8.96}$ is formed in the range $10^{-20}<\mathrm{pO}_{2}<10^{-18} \mathrm{~Pa}$, whereas below $10^{-20} \mathrm{~Pa}$, the amorphous $\mathrm{La}_{2} \mathrm{Mo}_{2} \mathrm{O}_{7-y}$ form is obtained.
In the present paper, the kinetic aspect of $\mathrm{La}_{2} \mathrm{Mo}_{2} \mathrm{O}_{9}$ reduction to the amorphous forms is studied. For that purpose, powders from different synthesis routes with different specific surface areas and treated at two temperatures are used. The phase evolution during reduction is analyzed, and the stability of $\mathrm{La}_{2} \mathrm{Mo}_{2} \mathrm{O}_{7-y}$ is discussed. Reoxidation of the amorphous reduced phase is also studied.

\section{EXPERIMENTAL SECTION}

Synthesis of $\mathrm{La}_{2} \mathrm{Mo}_{2} \mathrm{O}_{9}$ Powders. Two synthesis routes were used in order to obtain powders with different sizes and shapes of particles and therefore different specific surface areas of the samples. First, $\mathrm{La}_{2} \mathrm{Mo}_{2} \mathrm{O}_{9}$ powders were prepared by solid state reaction (SSR). $\mathrm{La}_{2} \mathrm{O}_{3}$ and $\mathrm{MoO}_{3}$ were weighed in stoichiometric amounts and mixed in an agate mortar with acetone. $\mathrm{La}_{2} \mathrm{O}_{3}$ was previously dehydrated and decarbonated at $1000{ }^{\circ} \mathrm{C}$ for $12 \mathrm{~h}$. The mixed oxides were annealed at $500{ }^{\circ} \mathrm{C}$ for $12 \mathrm{~h}$ in order to avoid Mo oxide sublimation and then heat treated twice at $900{ }^{\circ} \mathrm{C}$ for $12 \mathrm{~h}$. The powders were ground between each heat treatment. $\mathrm{La}_{2} \mathrm{Mo}_{2} \mathrm{O}_{9}$ powders with higher specific surface areas were also prepared by the polyol process using two glycol solvents, ethylene glycol (EG) and diethylene glycol (DEG), with a final rapid heat treatment of $5 \mathrm{~min}$ at $600{ }^{\circ} \mathrm{C} .{ }^{17}$ The details regarding this synthesis are reported in previous papers by Sellemi et al. ${ }^{18,19}$

Hydrogen Reduction and Reoxidation Characterization. Reduction kinetics of $\mathrm{La}_{2} \mathrm{Mo}_{2} \mathrm{O}_{9}$ was studied at 700 and $760{ }^{\circ} \mathrm{C}$ using a Setaram TG92 microbalance under a flow rate of $4.8 \mathrm{~L} \cdot \mathrm{h}^{-1}$ of $10 \% \mathrm{H}_{2}$ diluted in Ar. A quartz crucible was used as a container for the reduction. The furnace with crucible and powder in it was first purged in the hydrogen-diluted atmosphere for $1 \mathrm{~h}$ at room temperature before heating the sample up to high temperature with a fast rate of $30^{\circ} \mathrm{C}$. $\mathrm{min}^{-1}$. The sample weight was corrected from the effect of Archimede pressure by subtracting, from the measurement performed on the sample, the measurement performed on the empty quartz crucible under the same conditions. Since powders prepared by solid state reaction and by the polyol process have very different specific surface areas (see Table 1 from the BET measurements), we preferred to use for each

Table 1. Specific Surface Areas, According to the BET Method, of Powders Obtained by SSR and Polyol Process

synthesis
SSR
EG
DEG

specific surface area
$<1 \mathrm{~m}^{2} \cdot \mathrm{g}^{-1}$
$6.0(3) \mathrm{m}^{2} \cdot \mathrm{g}^{-1}$

measurement the same occupied volume in the crucible rather than the same mass. Around 300, 150, and $50 \mathrm{mg}$ of raw samples were used, respectively, for SSR, EG, and DEG sample for each TG measurement.

The reoxidation of $\mathrm{La}_{2} \mathrm{Mo}_{2} \mathrm{O}_{7-y}$ for 12 and $60 \mathrm{~h}$ was performed under flowing air in the same thermogravimetric apparatus. The measurements were carried out in a quartz crucible containing about $50 \mathrm{mg}$ of raw samples.

Other thermal analyses for the study of the reoxidation were carried out in air with a TGA/DTA Q600 SDT TA Instruments apparatus under a flow rate of $6 \mathrm{~L} \cdot \mathrm{h}^{-1}$ with a heating/cooling rate of $10^{\circ} \mathrm{C} \cdot \mathrm{min}^{-1}$ using platinum crucibles with $\mathrm{Al}_{2} \mathrm{O}_{3}$ as a reference.

Characterization Techniques. X-ray powder diffraction (XRPD) patterns were recorded at room temperature on a PANalytical $\theta / \theta$ Bragg-Brentano X'pert MPD PRO diffractometer ( $\mathrm{Cu}$ K $\alpha$ radiations) equipped with the $\mathrm{X}^{\prime}$ Celerator detector. Step and recording speed were $0.03^{\circ}$ and $53 \mathrm{~s} / \mathrm{step}$ for regular patterns and $0.03^{\circ}$ and $440 \mathrm{~s} / \mathrm{step}$ for Rietveld quantification, respectively.

$\mathrm{N}_{2}$ adsorption measurements were performed at $77 \mathrm{~K}$ on a Micromeritics Tristar II system (Micromeretics, Norcross, GA). Approximately $260 \mathrm{mg}$ and $1.9 \mathrm{~g}$ of powders were employed, respectively, for EG/DEG and SSR sample in each measurement. The specific surface area was calculated using the Brunauer-Emmet-Teller (BET) model in the range of around $0.06<P / P_{0}<1$. 

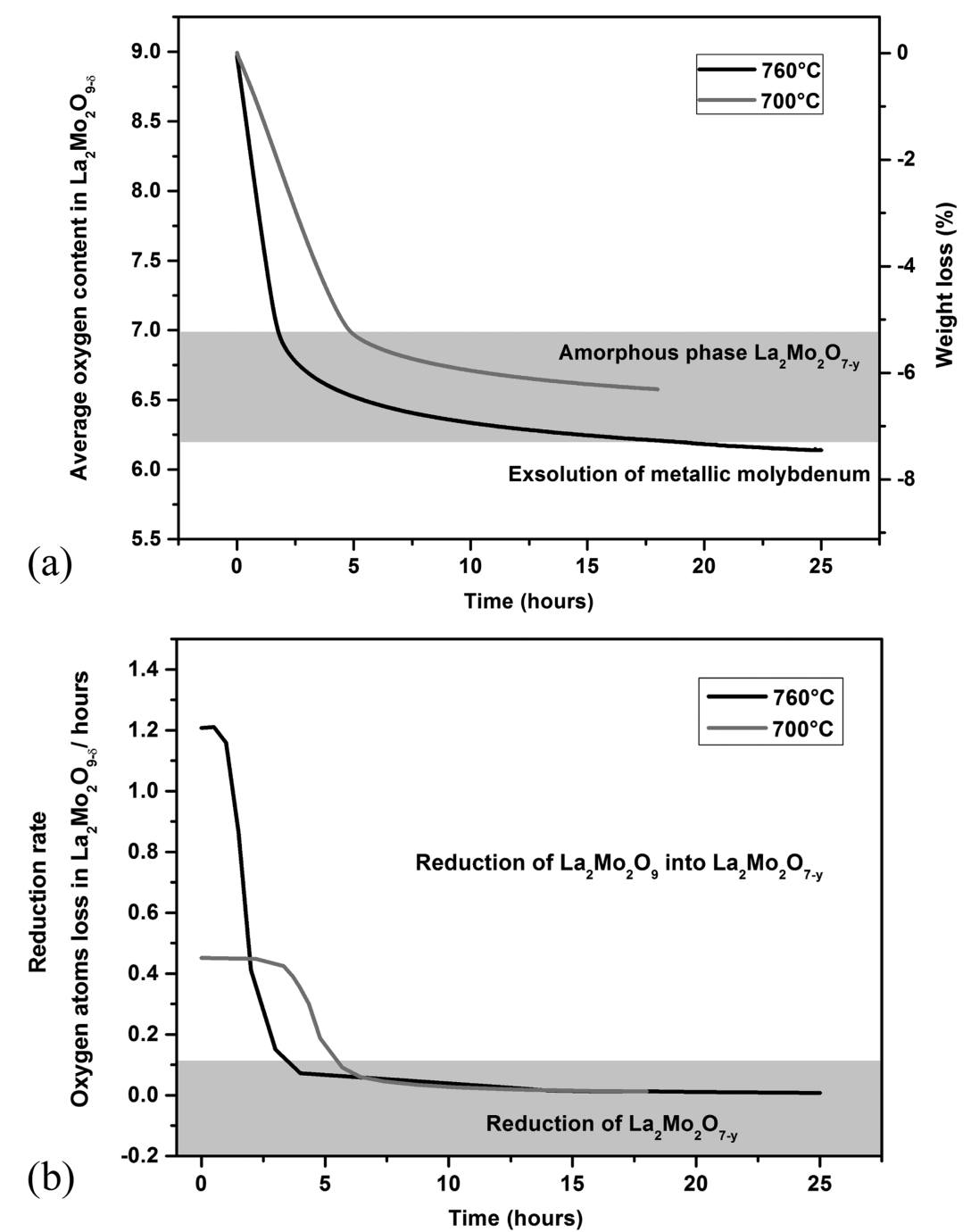

Figure 2. Thermogravimetric measurements of $\mathrm{La}_{2} \mathrm{Mo}_{2} \mathrm{O}_{9}$ reduction at 700 and $760{ }^{\circ} \mathrm{C}$ under $10 \% \mathrm{H}_{2} / \mathrm{Ar}$ for SSR sample: (a) Average oxygen content versus time; (b) reduction rate versus time.

\section{RESULTS AND DISCUSSION}

Hydrogen Reduction of $\mathrm{La}_{2} \mathrm{Mo}_{2} \mathrm{O}_{9}$. The reduction of $\mathrm{La}_{2} \mathrm{Mo}_{2} \mathrm{O}_{9}$ was characterized in situ by thermogravimetric analysis, the weight loss being assumed to result from a loss of oxygen atoms according to the following reaction

$$
\mathrm{La}_{2} \mathrm{Mo}_{2} \mathrm{O}_{9}+z \mathrm{H}_{2(\mathrm{~g})} \rightarrow \mathrm{La}_{2} \mathrm{Mo}_{2} \mathrm{O}_{9-z}+z \mathrm{H}_{2} \mathrm{O}_{(\mathrm{g})}
$$

Reduction kinetics of the sample is determined by plotting the evolution with time of the mass and, therefore, of the oxygen content at a fixed temperature under constant flowing atmosphere. In the first part, the mechanism and reduction kinetics are compared at different temperatures, 700 and $760^{\circ} \mathrm{C}$, on the SSR sample. In the second part, a comparison is made for powder samples having different specific surface areas.

Effect of the Reduction Temperature. Two different temperatures, 700 and $760{ }^{\circ} \mathrm{C}$, were used for the reduction of $\mathrm{La}_{2} \mathrm{Mo}_{2} \mathrm{O}_{9}$ compounds synthesized by solid state reaction. A temperature of $760{ }^{\circ} \mathrm{C}$ was chosen with respect to the previous work by Goutenoire et al. ${ }^{7}$ We also chose a temperature of 700 ${ }^{\circ} \mathrm{C}$ because it is close to the operating temperature expected for an intermediate temperature SOFC and for the different phase change during reduction compared to what happens at $760{ }^{\circ} \mathrm{C}$, as described hereafter. The reduction kinetics is presented in Figure
2 through the average oxygen content versus time (Figure 2a) and the time dependence of the reduction rate (Figure $2 b$ ), calculated from the derivative vs time of the oxygen loss per formula unit. Phase evolution during reduction was followed by X-ray powder diffraction (XRPD) after cooling the sample down to room temperature from different reduction temperatures in diluted hydrogen. For a reduction temperature of $760^{\circ} \mathrm{C}$ (Figure $3 \mathrm{a}$ ), after $30 \mathrm{~min}$, three phases can be identified as $\mathrm{La}_{2} \mathrm{Mo}_{2} \mathrm{O}_{9}$, $\mathrm{La}_{7} \mathrm{Mo}_{7} \mathrm{O}_{30}\left(\mathrm{La}_{2} \mathrm{Mo}_{2} \mathrm{O}_{8.57}\right)$, and an amorphous phase detected through the background undulation, whereas after $2 \mathrm{~h}$ of reduction only the amorphous phase and crystallized $\mathrm{La}_{7} \mathrm{Mo}_{7} \mathrm{O}_{30}$ compound are present. The amount of $\mathrm{La}_{7} \mathrm{Mo}_{7} \mathrm{O}_{30}$ decreases with time, resulting in a pure amorphous phase after a few hours. Further reduction of the amorphous $\mathrm{La}_{2} \mathrm{Mo}_{2} \mathrm{O}_{6.2}$ phase induces the exsolution of metallic molybdenum, which started being detected after $20 \mathrm{~h}$ annealing. It implies a substoichiometry in molybdenum in the amorphous phase. However, for a reduction temperature of $700{ }^{\circ} \mathrm{C}$ (Figure $3 \mathrm{~b}$ ), during the first $6 \mathrm{~h}$ a direct progressive amorphization of the $\mathrm{La}_{2} \mathrm{Mo}_{2} \mathrm{O}_{9}$ phase is observed, with disappearance of the peaks corresponding to crystallized domains until complete amorphization. XRD and thermogravimetric analyses show two reduction regimes (see Figure $2 \mathrm{~b}$ ). The first regime corresponds to the reduction of $\mathrm{La}_{2} \mathrm{Mo}_{2} \mathrm{O}_{9}$ into 

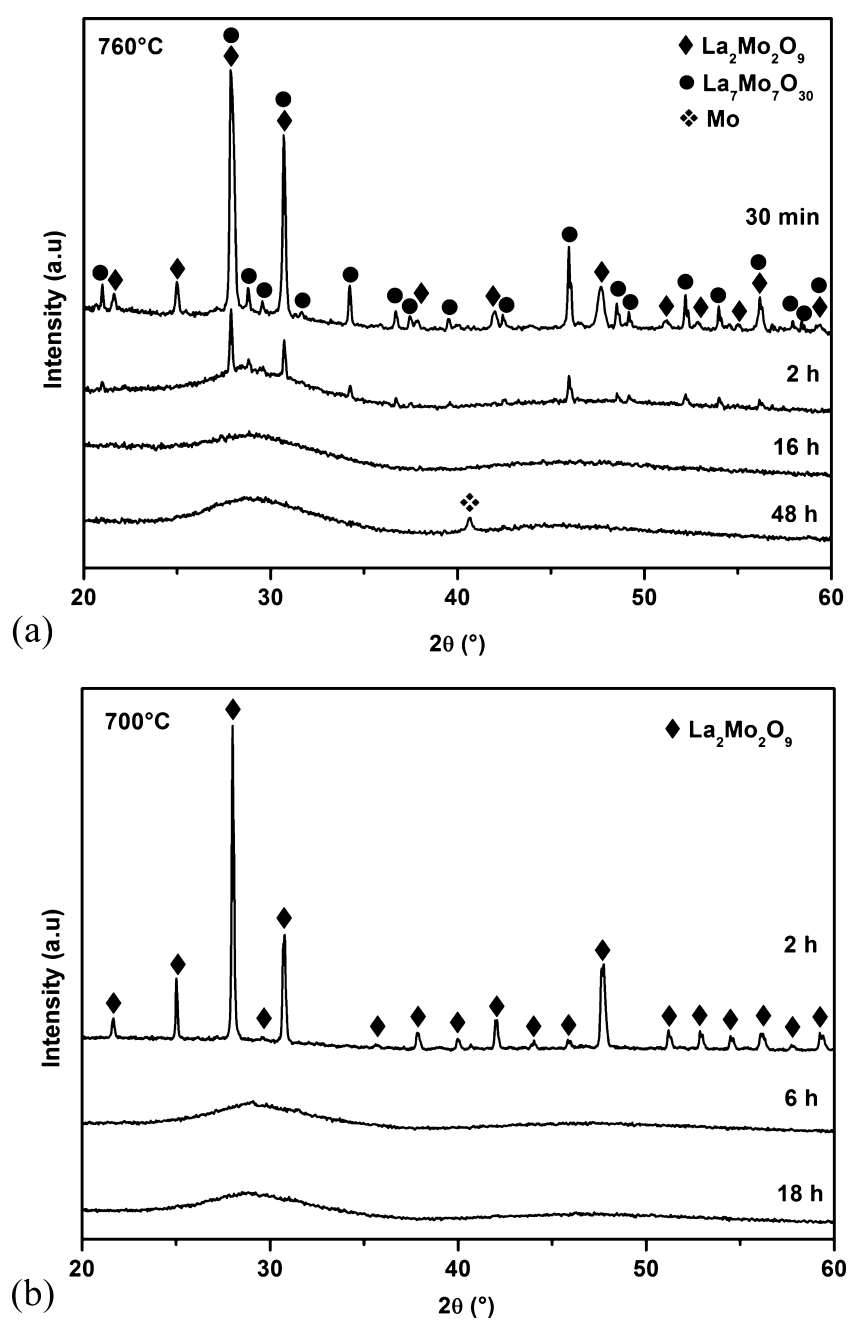

Figure 3. XRD patterns of the phase evolution of $\mathrm{La}_{2} \mathrm{Mo}_{2} \mathrm{O}_{9} \mathrm{SSR}$ samples during reduction at (a) 760 and (b) $700{ }^{\circ} \mathrm{C}$.

amorphous $\mathrm{La}_{2} \mathrm{Mo}_{2} \mathrm{O}_{7}$ and the second one to the reduction of the amorphous phase and exsolution of metallic molybdenum from it when further reduced. For the first regime, the reduction rate depends on temperature: 0.4 and 1.2 oxygen atoms loss per unit cell and per hour at 700 and $760{ }^{\circ} \mathrm{C}$, respectively. However, in the second regime, the reduction rate does not seem to depend on temperature: after $18 \mathrm{~h}$ it is 0.012 both at 700 and $760{ }^{\circ} \mathrm{C}$. After $25 \mathrm{~h}$ at $760^{\circ} \mathrm{C}$, the reduction rate is 0.009 . According to the $\mathrm{XRD}$ patterns, the mechanisms occurring during the reduction at 700 and $760{ }^{\circ} \mathrm{C}$ are different. Reduction at $700{ }^{\circ} \mathrm{C}$ does not occur through the intermediate phase $\mathrm{La}_{7} \mathrm{Mo}_{7} \mathrm{O}_{30}$, which is consistent with previous papers on the formation of $\mathrm{La}_{7} \mathrm{Mo}_{7} \mathrm{O}_{30}$ : Goutenoire et al. synthesized this phase by reduction of $\mathrm{La}_{2} \mathrm{Mo}_{2} \mathrm{O}_{9}$ under a flow of $6 \% \mathrm{H}_{2}$ and $94 \% \mathrm{~N}_{2}$ at $760{ }^{\circ} \mathrm{C}$, ${ }^{7}$ and Vega-Castillo et al. (see Figure 1) were able to stabilize this intermediate phase in the $\mathrm{pO}_{2}$ range of $10^{-17} \mathrm{~Pa}<\mathrm{pO}_{2}<10^{-11} \mathrm{~Pa}$ at $718{ }^{\circ} \mathrm{C}$, while at $608{ }^{\circ} \mathrm{C}$ no $\mathrm{La}_{7} \mathrm{Mo}_{7} \mathrm{O}_{30}$ phase was detected above $10^{-20} \mathrm{~Pa} \mathrm{O}_{2}{ }^{10}$

Effect of the Powder Specific Surface Area. The reduction kinetics was studied at $700{ }^{\circ} \mathrm{C}$ on powders with different specific surface areas. The starting powders used were synthesized by solid state reaction and by the polyol process using ethylene glycol (EG) and diethylene glycol (DEG). The specific surface areas measured by the BET method are reported in Table 1 . High values are obtained for the powder samples prepared by the polyol process, for very thin platelet particles synthesized with DEG, and porous spherical grains synthesized with EG. ${ }^{18,19}$ Reduction kinetics are presented in Figure 4a. We can notice for EG and DEG samples that reduction has already begun during the heating process. As expected, the kinetics is higher for powders prepared by the polyol process. After $18 \mathrm{~h}$ of reduction, oxygen stoichiometries $x$ of $\mathrm{La}_{2} \mathrm{Mo}_{2} \mathrm{O}_{x}$ samples obtained by SSR, DEG, and EG are 6.57, 6.04, and 6.11, respectively. In Figure $4 \mathrm{~b}$ are shown the reduction rates calculated from the derivative vs time of oxygen loss. As previously shown, two reduction regimes are observed: one corresponding to the reduction of $\mathrm{La}_{2} \mathrm{Mo}_{2} \mathrm{O}_{9}$ and the other to the reduction of amorphous phase $\mathrm{La}_{2} \mathrm{Mo}_{2} \mathrm{O}_{7}$. The average reduction rates of the first regime are consistent with the specific surface areas. DEG sample has the highest average reduction rate of 4.1 atoms lost per unit cell per hour, whereas average reduction rates of EG and SSR samples are 3.1 and 0.4, respectively. Reduction kinetics of the powder obtained with EG is only slightly smaller than that of the powder obtained with DEG despite a factor of about 3 between the two specific surface areas. This difference could be explained by the morphology of the particles; the DEG process produces platelet particles, while EG leads to spherical grains. Then it indicates that spherical morphology seems to favor the phase reduction.

Concerning the second regime, the reduction rate is the same for the three samples. It seems that the reduction of the amorphous phase is influenced neither by the temperature nor by the microstructure of the original particles. It might be due to the fragmentation of the platelets/grains during the last part of the first reduction regime, resulting in amorphous subparticles of similar sizes whatever the raw sample. Phase evolution characterized by XRD shows first a reduction into the amorphous phase without any formation of intermediate $\mathrm{La}_{7} \mathrm{Mo}_{7} \mathrm{O}_{30}$ phase for the DEG and EG samples. Then, as for the reduction at 760 ${ }^{\circ} \mathrm{C}$, an exsolution of metallic molybdenum from the amorphous phase is observed for severe reduction of polyol samples, resulting in an amorphous Mo-substoichiometric phase. In order to measure the weight fraction of metallic molybdenum, quantitative Rietveld analyses of the amorphous and molybdenum metallic phases were carried out by XRD using the internal standard method. For this purpose, cerium oxide was used as the internal standard, because of its microabsorption coefficient close to those of metallic molybdenum and amorphous reduced phase. An exact amount of $10 \%$ in weight was added to the powders analyzed by XRD. The internal standard method is based on the calculation of the weight fraction of each compound

$$
W_{j}=\frac{S_{j} \times\left(Z_{j} \times M_{j} \times V_{j}\right)}{\sum_{i} S_{i} \times\left(Z_{i} \times M_{i} \times V_{i}\right)}
$$

where $W_{j}$ is the weight fraction of phase $j, S_{j}$ is the Rietveld scale factor of phase $j, Z_{j}$ is the number of formula units per cell of phase $j, M_{j}$ is the mass of formula unit of phase $j$, and $V_{j}$ is the volume unit cell of phase $j$.

Quantitative Rietveld analyses were performed on two samples of DEG reduced for 17 and $34 \mathrm{~h}$, for which the scale factor was determined. Figure 5 presents Rietveld analysis on the XRD pattern of the $34 \mathrm{~h}$ reduced sample. The quantification of the weight fraction of metallic molybdenum and amorphous phase allowed us to determine the stoichiometry of this last one, as summarized in Table 2. Compositions after 17 and $34 \mathrm{~h}$ of reduction are $\mathrm{La}_{2} \mathrm{Mo}_{1.95} \mathrm{O}_{6.05}$ and $\mathrm{La}_{2} \mathrm{Mo}_{1.94} \mathrm{O}_{5.90}$, respectively. In these compositions, molybdenum cations present average oxidation states of +3.1 and +3.0 , respectively. 

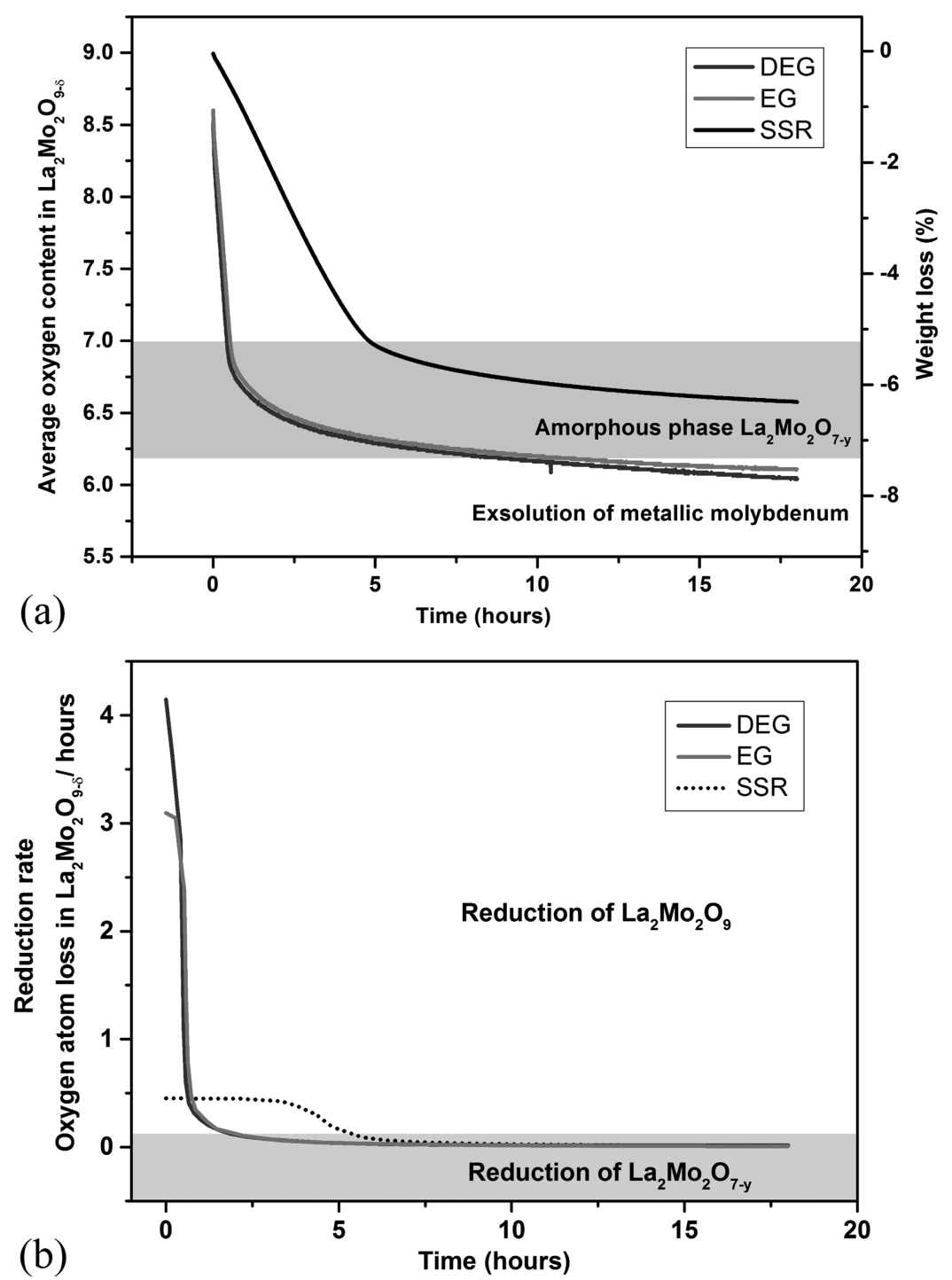

Figure 4. Thermogravimetric measurements of $\mathrm{La}_{2} \mathrm{Mo}_{2} \mathrm{O}_{9}$ reduction at $700{ }^{\circ} \mathrm{C}$ under $10 \% \mathrm{H}_{2} / \mathrm{Ar}$ for SSR, DEG, and EG samples: (a) Average oxygen versus time (SSR = upper curve); (b) reduction rate versus time.

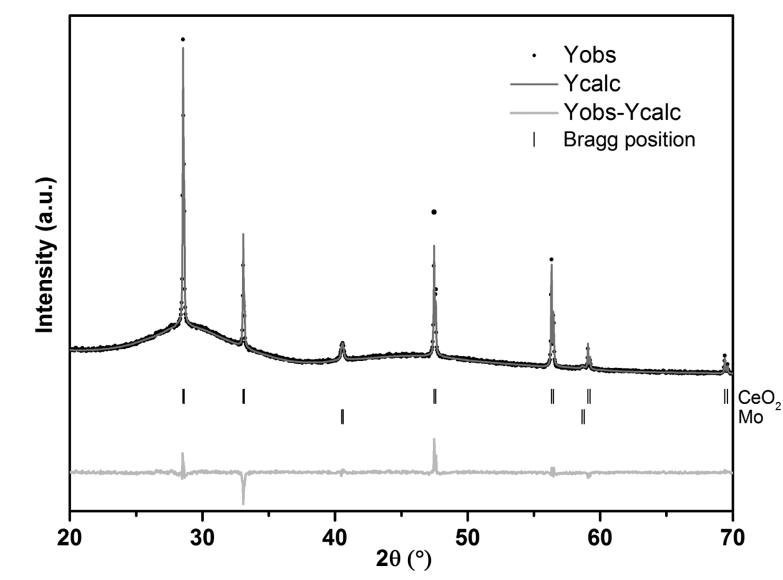

Figure 5. Results of the quantitative Rietveld analyses of the amorphous and molybdenum phases on the DEG sample reduced $34 \mathrm{~h}$ at $700{ }^{\circ} \mathrm{C}$ under $10 \% \mathrm{H}_{2} / \mathrm{Ar}$, with cerium oxide as internal standard $\left(R_{\mathrm{p}}=22.8 \%\right.$, $\left.R_{\text {wp }}=18 \%, R_{\exp }=8.07 \%, \chi^{2}=5 \%\right)$.

Mathematical Modeling of the Reduction Kinetics. On the basis of TGA analysis and on the phase evolution of the
Table 2. Results of the Quantitative Rietveld Analyses of the Metallic Molybdenum and Amorphous Phases Using the Internal Standard Method

\begin{tabular}{ccccc}
$\begin{array}{c}\text { reduction } \\
\text { time }\end{array}$ & $\begin{array}{c}\text { oxygen } \\
\text { loss }\end{array}$ & $\begin{array}{c}\text { amorphous weight } \\
\text { fraction }\end{array}$ & $\begin{array}{c}\text { Mo weight } \\
\text { fraction }\end{array}$ & formula \\
$17 \mathrm{~h}$ & $7.76 \%$ & $99.2 \%$ & $0.80 \%$ & $\begin{array}{c}\mathrm{La}_{2} \mathrm{Mo}_{1.95} \mathrm{O}_{6.05} \\
0.05 \mathrm{Mo}\end{array}$ \\
$34 \mathrm{~h}$ & $8.09 \%$ & $98.9 \%$ & $1.10 \%$ & $\begin{array}{c}\mathrm{La}_{2} \mathrm{Mo}_{1.94} \mathrm{O}_{5.90} \\
0.06 \mathrm{Mo}\end{array}$ \\
\hline
\end{tabular}

compound determined by XRD, a modeling of the reduction kinetics was performed using a kinetic law developed by Bessières et al. for the reduction of iron oxide. ${ }^{20,21}$ The motivation for such type of model rests on the shape of the reduction rate curves, which does not pass through a maximum with time as would be the case if the reduction kinetics were nucleation limited. ${ }^{22}$ The decrease in reduction rate with time shows that here nucleation is very fast, and in this case, a "shrinking core model" is usually used to describe kinetics. ${ }^{23}$ The Bessières model we used is based on a chemical reaction interface which progresses with a constant rate $V_{c}$, being proportional to 
the concentration of the reducing gases and to the area of the reaction interface

$$
V_{c}=B\left(C_{\mathrm{o}}-C^{*}\right) 4 \pi R_{i}^{2}
$$

In this model, chemical reactions can take place either separately or simultaneously at the different interfaces. Figure 6 presents an

(a)

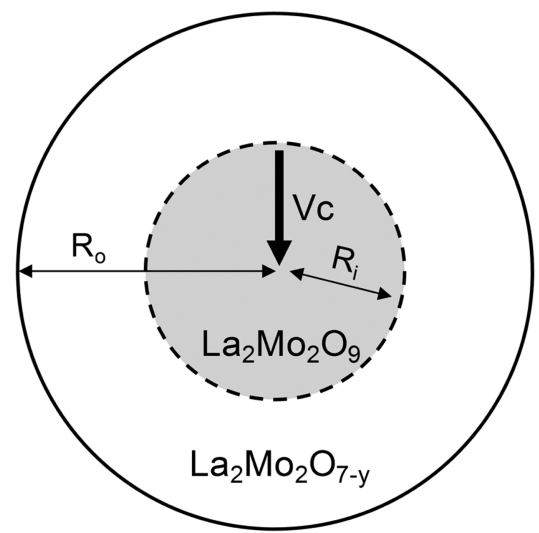

(b)

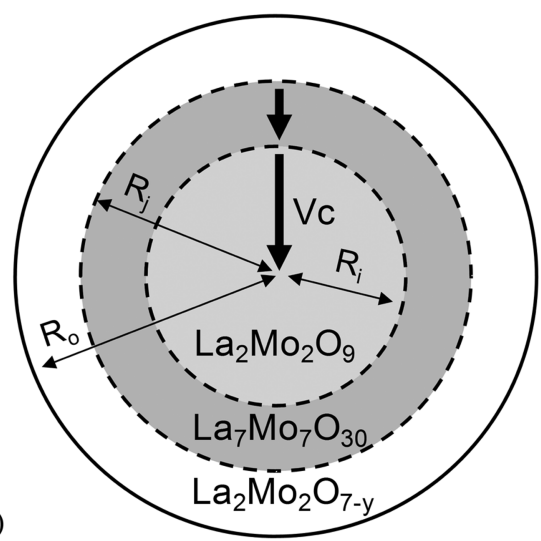

Figure 6. Illustration of the kinetic law model with interface progression for (a) a single reaction and (b) a double reaction.

illustration of this kinetic law model in the case of spherical grains with either one or two reactions progressing. The kinetic law is of first order and can be expressed as

$$
\frac{R_{\mathrm{o}}-R_{i}}{R_{\mathrm{o}}}=1-X_{i}^{1 / 3}=\frac{B\left(C_{\mathrm{o}}-C^{*}\right)}{R_{\mathrm{o}} m q_{i}} t=\frac{t}{\left(t f_{c}\right)_{i}}=k_{i} t
$$

where $C_{\mathrm{o}}$ is the reducing gas concentration, $C^{*}$ is the equilibrium concentration of the gas with the two oxides present, $B$ is a constant depending on the temperature, $R_{\mathrm{o}}$ is the initial particle radius, $R_{i}$ is the interface radius of reaction $i, m$ is the mass of the oxygen atom, $q$ is the number of oxygen atoms to be taken away per unit volume for the reaction considered, $\left(\mathrm{tf}_{\mathrm{c}}\right)_{i}$ is the time needed to obtain the total reduction of the interface in the pure chemical reaction, $X_{i}$ is $R_{i}^{3} / R_{0}^{3}, 1-X_{i}$ is the progress of the reduction, $1-X_{i}^{1 / 3}$ is the relative penetration, and $k_{i}$ is the reaction rate.

Thermogravimetric data allow us to calculate the progress of the global reaction $1-X$, where $X=\sum_{i}\left(\alpha_{i} X_{i}\right)$ and $\alpha_{i}$ are the coefficients depending on the oxygen loss for each single reaction (三 proportion of lost oxygen for each reaction). From the progress of the global reaction we can plot the relative penetration $1-X^{1 / 3}$ as a function of time. Assuming this type of kinetic law we can study the evolution of each interface as a function of time. The kinetic law for a single reaction can be expressed as

$$
1-X_{i}^{1 / 3}=k_{i} t
$$

However, when a reaction begins with a delay time it becomes

$$
1-X_{i}^{1 / 3}=k_{i}\left(t-t_{0}\right)
$$

where $t_{0}$ is the time delay.

Then $X_{i}$ values of the single reaction of eqs 5 and 6 are, respectively

$$
\begin{aligned}
& X_{i}=\left(1-k_{i} t\right)^{3} \\
& X_{i}=\left(1-k_{i}\left(t-t_{0}\right)\right)^{3}
\end{aligned}
$$

The total reduction time of a single interface $(\mathrm{tfc})_{i}$ can be calculated from the kinetic constant $k_{i}$

$$
(\mathrm{tfc})_{i}=\frac{1}{k_{i}}
$$

The relative deviation ( $\mathrm{RD}$ ) between experimental (1 $\left.X^{1 / 3}\right)_{\exp }$ and calculated $\left(1-X^{1 / 3}\right)_{\text {calcd }}$ curves has been calculated as follows

$$
\mathrm{RD}(\%)=\frac{\sum \mathrm{I}\left(1-X^{1 / 3}\right)_{\text {calcd }}-\left(1-X^{1 / 3}\right)_{\exp } \mid}{\sum\left(1-X^{1 / 3}\right)_{\text {calcd }}} \times 100
$$

Since this kinetic law is based on spherical particles, only the reduction made on the SSR and EG samples were fitted.

Let us start with the model of the SSR sample reduced at 700 ${ }^{\circ} \mathrm{C}$. The following reactions are deduced from the XRD and TGA observations presented previously

$$
\text { Reaction A: } \mathrm{La}_{2} \mathrm{Mo}_{2} \mathrm{O}_{9} \rightarrow \mathrm{La}_{2} \mathrm{Mo}_{2} \mathrm{O}_{7-y} \alpha_{\mathrm{A}}=\frac{2+y}{2.8}
$$

$$
\text { Reaction B: } \mathrm{La}_{2} \mathrm{Mo}_{2} \mathrm{O}_{7-y} \rightarrow \mathrm{La}_{2} \mathrm{Mo}_{2} \mathrm{O}_{6.2} \quad \alpha_{\mathrm{B}}=\frac{0.8-y}{2.8}
$$

Reaction $\mathrm{A}$ is the reduction of $\mathrm{La}_{2} \mathrm{Mo}_{2} \mathrm{O}_{9}$ into the amorphous phase $\mathrm{La}_{2} \mathrm{Mo}_{2} \mathrm{O}_{7-y}$. However, it seems that the oxygen stoichiometry for which the amorphous phase starts is not well defined. According to the literature, ${ }^{8,10} y$ should be between 0 and 0.3. Reaction $B$ is the reduction of the amorphous phase until the start of metallic molybdenum exsolution.

During the first period, there are two interfaces present at the same time, with reactions A and B proceeding simultaneously. The relative penetration is given by the following relation

$$
1-X^{1 / 3}=1-\left[\alpha_{\mathrm{A}}\left(1-k_{\mathrm{A}} t\right)^{3}-\alpha_{\mathrm{B}}\left(1-k_{\mathrm{B}} t\right)^{3}\right]^{1 / 3}=g(t)
$$

The slope at the origin of $g(t)$ is given by its derivative for $t=0$

$$
g^{\prime}(0)=\alpha_{\mathrm{A}} k_{\mathrm{A}}+\alpha_{\mathrm{B}} k_{\mathrm{B}}
$$

Hereafter, when reaction A is finished, there is only one chemical reaction front $(B)$. In this case the relative penetration is given by the following relation

$$
1-X^{1 / 3}=1-\left[\alpha_{\mathrm{B}}\left(1-k_{\mathrm{B}} t\right)^{3}\right]^{1 / 3}=1-\alpha_{\mathrm{B}}^{1 / 3}+\alpha_{\mathrm{B}}^{1 / 3} k_{\mathrm{B}} t
$$




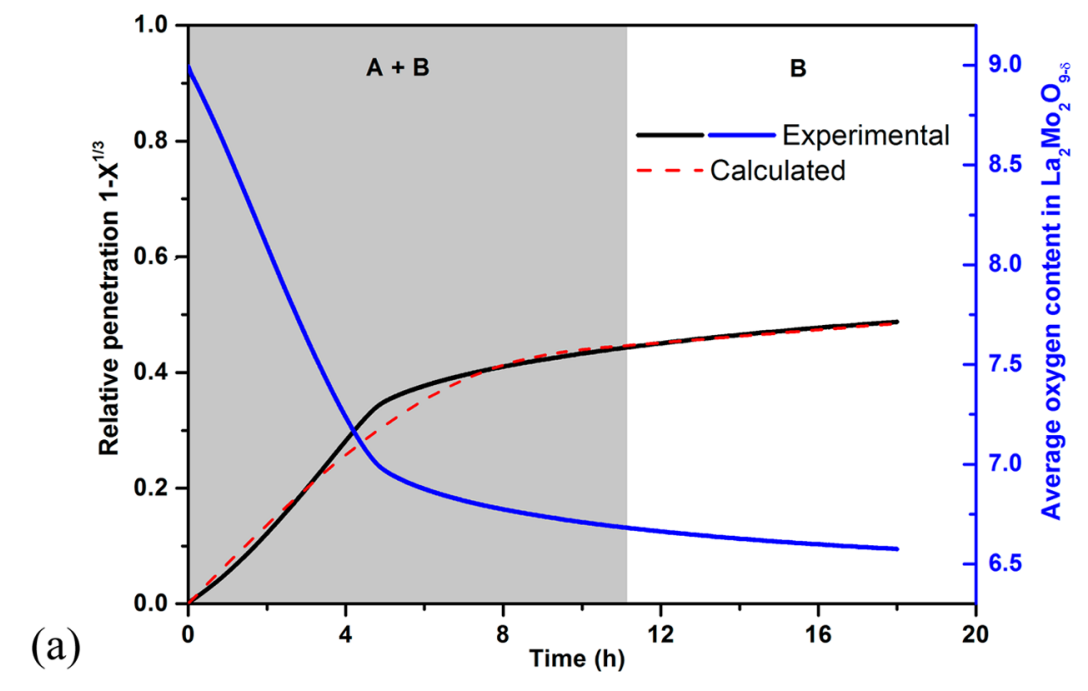

(a)

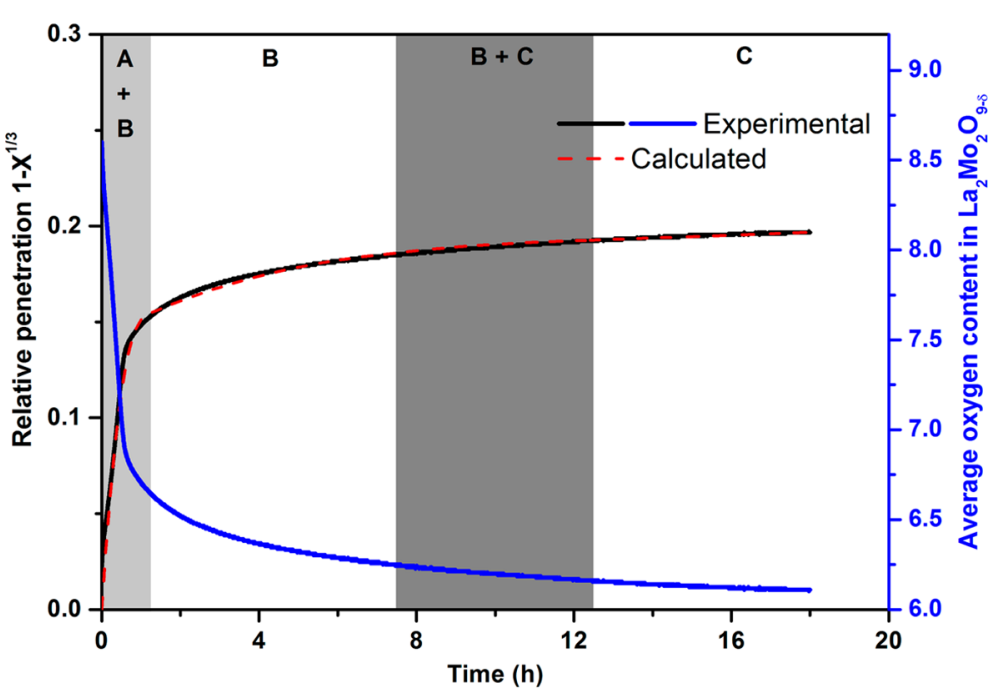

(b)

(c)

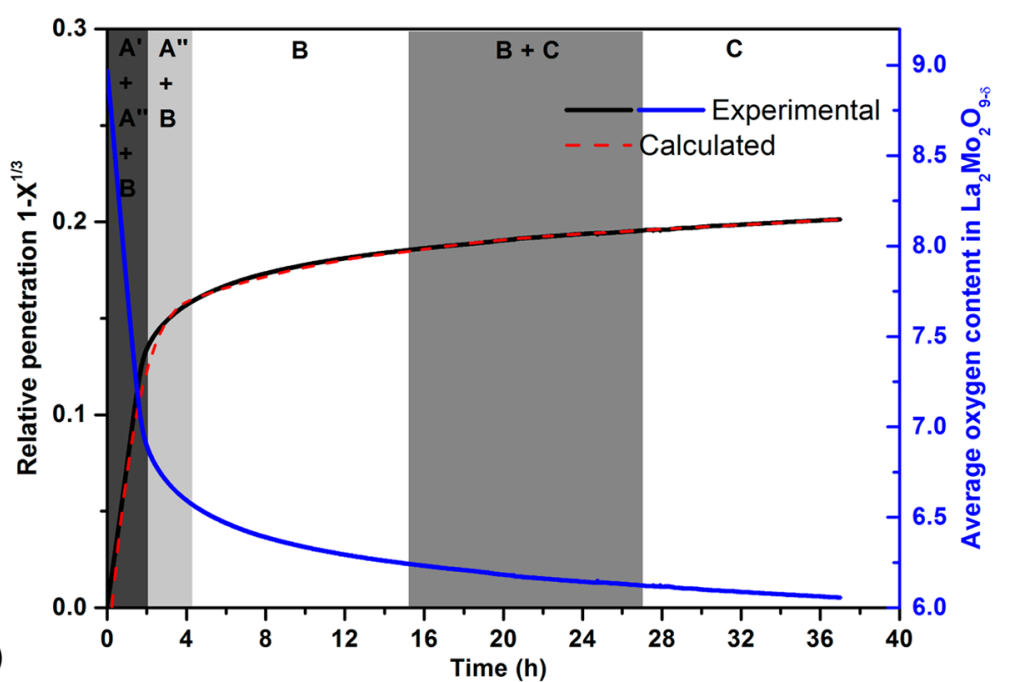

Figure 7. Relative penetration and average oxygen content in $\mathrm{La}_{2} \mathrm{Mo}_{2} \mathrm{O}_{9-\delta}$ versus time of reduction under $10 \% \mathrm{H}_{2} / \mathrm{Ar}$ at $(\mathrm{a}) 700^{\circ} \mathrm{C}$ on SSR sample, (b) $700{ }^{\circ} \mathrm{C}$ on EG sample, and (c) $760{ }^{\circ} \mathrm{C}$ on SSR sample.

Experimental data of the ordinate at the origin $\left(1-\alpha_{\mathrm{B}}^{1 / 3}\right)$ and the slope $\left(\alpha_{\mathrm{B}}^{1 / 3} k_{\mathrm{B}}\right)$ in the range where only reaction $\mathrm{B}$ occurs allow us to calculate $\alpha_{\mathrm{B}}$ and the reaction constant $k_{\mathrm{B}}$. Finally, from expression 14, $k_{\mathrm{A}}$ can be calculated. Experimental data and the associated fit are presented in Figure $7 \mathrm{a}$, and fitted parameters of each single reaction reported in Table 3.
The fit is poor in the 4-6 h time interval, probably due to the assumption of fast nucleation of our model, whereas the penetration curve shows a slight tendency to a sigmoidal character during the first $6 \mathrm{~h}$.

Contrary to the previous SSR sample, in the case of the EG sample reduced at $700{ }^{\circ} \mathrm{C}$, a third reaction is present which 
Table 3. Summary of the Parameters of Each Single Reaction Obtained by Modelization of the Kinetic Reduction

\begin{tabular}{|c|c|c|c|}
\hline & $\begin{array}{l}\text { SSR sample } \\
\text { reduction } 760{ }^{\circ} \mathrm{C}\end{array}$ & $\begin{array}{l}\text { SSR sample } \\
\text { reduction } 700{ }^{\circ} \mathrm{C}\end{array}$ & $\begin{array}{c}\text { EG sample } \\
\text { reduction } 700{ }^{\circ} \mathrm{C}\end{array}$ \\
\hline$k_{\mathrm{A}}$ & & $0.090 \mathrm{~h}^{-1}$ & $0.80 \mathrm{~h}^{-1}$ \\
\hline$(\mathrm{tfc})_{\mathrm{A}}$ & & $11 \mathrm{~h}$ & $1.3 \mathrm{~h}$ \\
\hline$\alpha_{\mathrm{A}}$ & & 0.768 & 0.370 \\
\hline$k_{\mathrm{A}^{\prime}}$ & $0.50 \mathrm{~h}^{-1}$ & & \\
\hline$(\mathrm{tfc})_{\mathrm{A}^{\prime}}$ & $2.0 \mathrm{~h}$ & & \\
\hline$\alpha_{\mathrm{A}^{\prime}}$ & 0.072 & & \\
\hline$k_{\mathrm{A}^{\prime \prime}}$ & $0.23 \mathrm{~h}^{-1}$ & & \\
\hline$(\mathrm{tfc})_{\mathrm{A}^{\prime \prime}}$ & $4.3 \mathrm{~h}$ & & \\
\hline$\alpha_{\mathrm{A}^{\prime \prime}}$ & 0.298 & & \\
\hline$k_{\mathrm{B}}$ & $0.037 \mathrm{~h}^{-1}$ & $0.0090 \mathrm{~h}^{-1}$ & $0.080 \mathrm{~h}^{-1}$ \\
\hline$(t f c)_{B}$ & $27 \mathrm{~h}$ & $1.1 \times 10^{2} \mathrm{~h}$ & $12.5 \mathrm{~h}$ \\
\hline$\alpha_{\mathrm{B}}$ & 0.097 & 0.232 & 0.097 \\
\hline$y$ & 0.22 & 0.15 & 0.22 \\
\hline$k_{\mathrm{C}}$ & $0.70 \times 10^{-3} \mathrm{~h}^{-1}$ & & $0.90 \times 10^{-3} \mathrm{~h}^{-1}$ \\
\hline$(t f c)_{C}$ & $1.4 \times 10^{3} \mathrm{~h}$ & & $1.1 \times 10^{3} \mathrm{~h}$ \\
\hline$\alpha_{\mathrm{C}}$ & 0.533 & & 0.533 \\
\hline$t_{0}$ & $15.2 \mathrm{~h}$ & & $7.44 \mathrm{~h}$ \\
\hline $\mathrm{RD}$ & $0.48 \%$ & $2.60 \%$ & $0.67 \%$ \\
\hline
\end{tabular}

corresponds to the reduction of the amorphous phase into metallic molybdenum (reaction $\mathrm{C}$ ). On the basis of XRD and TGA observations, reaction $\mathrm{C}$ seems to start around amorphous composition $\mathrm{La}_{2} \mathrm{Mo}_{2} \mathrm{O}_{6.2}$, i.e., this reaction starts with a time delay $t_{0}$ compared to the initial stage time $t=0$. Since reduction seems to evolve continuously, we assumed that this reduction step ends when all molybdenum is reduced to the metal, lanthanum remaining under the form of elementary oxide $\mathrm{La}_{2} \mathrm{O}_{3}$.

$$
\text { Reaction A: } \mathrm{La}_{2} \mathrm{Mo}_{2} \mathrm{O}_{9} \rightarrow \mathrm{La}_{2} \mathrm{Mo}_{2} \mathrm{O}_{7-y} \alpha_{\mathrm{A}}=\frac{2+y}{6}
$$

Reaction B: $\mathrm{La}_{2} \mathrm{Mo}_{2} \mathrm{O}_{7-y} \rightarrow \mathrm{La}_{2} \mathrm{Mo}_{2} \mathrm{O}_{6.2} \alpha_{\mathrm{B}}=\frac{0.8-y}{6}$

Reaction C: $\mathrm{La}_{2} \mathrm{Mo}_{2} \mathrm{O}_{6.2} \rightarrow \mathrm{La}_{2} \mathrm{O}_{3}+2 \mathrm{Mo} \alpha_{\mathrm{C}}=\frac{3.2}{6}$

During the first reduction step only reactions $\mathrm{A}$ and $\mathrm{B}$ are progressing at the same time. However, since reaction $C$ has not begun yet, the progress of this reaction $1-X_{C}=0$ and then

$$
X_{C}=1: X=\alpha_{\mathrm{A}} X_{\mathrm{A}}+\alpha_{\mathrm{B}} X_{\mathrm{B}}+\alpha_{\mathrm{C}}
$$

The relative penetration is given by the following equation

$$
1-X^{1 / 3}=1-\left[\alpha_{\mathrm{A}}\left(1-k_{\mathrm{A}} t\right)^{3}+\alpha_{\mathrm{B}}\left(1-k_{\mathrm{B}} t\right)^{3}+\alpha_{\mathrm{C}}\right]^{1 / 3}
$$

When reaction $\mathrm{A}$ ends and reaction $\mathrm{C}$ has not yet begun the relative penetration is

$$
1-X^{1 / 3}=1-\left[\alpha_{\mathrm{B}}\left(1-k_{\mathrm{B}} t\right)^{3}+\alpha_{\mathrm{C}}\right]^{1 / 3}
$$

Reaction $\mathrm{B}$ continues until the reaction front corresponding to the exsolution of metallic molybdenum starts with a time delay $t_{0}$ (reaction C). Two interfaces are then present at the same time (reactions $\mathrm{B}$ and $\mathrm{C}$ )

$$
1-X^{1 / 3}=1-\left[\alpha_{\mathrm{B}}\left(1-k_{\mathrm{B}} t\right)^{3}+\alpha_{\mathrm{C}}\left(1-k_{\mathrm{C}}\left(t-t_{0}\right)\right)^{3}\right]^{1 / 3}
$$

When the front of reaction $\mathrm{B}$ has vanished, only reaction $\mathrm{C}$ is present and the relative penetration is given by

$$
\begin{aligned}
1-X^{1 / 3} & =1-\left[\alpha_{\mathrm{C}}\left(1-k_{\mathrm{C}}\left(t-t_{0}\right)\right)^{3}\right]^{1 / 3} \\
& =1-\alpha_{\mathrm{C}}^{1 / 3}\left(1+k_{\mathrm{C}} t_{0}\right)+\alpha_{\mathrm{C}}^{1 / 3} k_{\mathrm{C}} t
\end{aligned}
$$

The ordinate at the origin $1-\alpha_{\mathrm{C}}^{1 / 3}\left(1+k_{\mathrm{C}} t_{0}\right)$ and the slope $\alpha_{\mathrm{C}}^{1 / 3} k_{\mathrm{C}}$ allow us to calculate the constant reaction $k_{\mathrm{c}}$ and therefore the time delay $t_{\mathrm{o}}$.

Fitting the relative penetration of each segment given by eqs 20, 21, 22, and 23 to the experimental data (Figure $7 \mathrm{~b}$ ) allows us to deduce the kinetic constants of each single reaction, which are reported in Table 3.

For the SSR sample reduced at $760{ }^{\circ} \mathrm{C}$, the process is quite more complex due to the existence of the intermediate phase $\mathrm{La}_{7} \mathrm{Mo}_{7} \mathrm{O}_{30}$ during the transformation into the amorphous phase $\mathrm{La}_{2} \mathrm{Mo}_{2} \mathrm{O}_{7-y}$ (reactions $\mathrm{A}^{\prime}$ and $\mathrm{A}^{\prime \prime}$ ). As previously shown, the exsolution of metallic molybdenum has been considered until reduction into primary oxide $\mathrm{La}_{2} \mathrm{O}_{3}+2 \mathrm{Mo}$.

Reaction $\mathrm{A}^{\prime}$ :

$$
\mathrm{La}_{2} \mathrm{Mo}_{2} \mathrm{O}_{9} \rightarrow \mathrm{La}_{7} \mathrm{Mo}_{7} \mathrm{O}_{30}\left(\mathrm{La}_{2} \mathrm{Mo}_{2} \mathrm{O}_{8.57}\right) \alpha_{\mathrm{A}^{\prime}}=\frac{0.43}{6}
$$

$$
\text { Reaction } \mathrm{A}^{\prime \prime}: \mathrm{La}_{7} \mathrm{Mo}_{7} \mathrm{O}_{30} \rightarrow \mathrm{La}_{2} \mathrm{Mo}_{2} \mathrm{O}_{7-y} \quad \alpha_{\mathrm{A}^{\prime \prime}}=\frac{1.57+y}{6}
$$

$$
\text { Reaction B: } \mathrm{La}_{2} \mathrm{Mo}_{2} \mathrm{O}_{7-y} \rightarrow \mathrm{La}_{2} \mathrm{Mo}_{2} \mathrm{O}_{6.2} \quad \alpha_{\mathrm{B}}=\frac{0.8-y}{6}
$$

$$
\text { Reaction C: } \mathrm{La}_{2} \mathrm{Mo}_{2} \mathrm{O}_{6.2} \rightarrow \mathrm{La}_{2} \mathrm{O}_{3}+2 \mathrm{Mo} \alpha_{\mathrm{C}}=\frac{3.2}{6}
$$

Successively, the same relations as previously shown can be associated as follows

$$
\begin{aligned}
& \text { Reaction } \mathrm{A}^{\prime}+\mathrm{A}^{\prime \prime}+\mathrm{B}: 1-\mathrm{X}^{1 / 3} \\
& \quad=1-\left[\alpha_{\mathrm{A}^{\prime}}\left(1-k_{\mathrm{A}^{\prime}} t\right)^{3}+\alpha_{\mathrm{A}^{\prime \prime}}\left(1-k_{\mathrm{A}^{\prime \prime}} t\right)^{3}+\alpha_{\mathrm{B}}\left(1-k_{\mathrm{B}} t\right)^{3}+\alpha_{\mathrm{C}}\right]^{1 / 3}
\end{aligned}
$$

$$
\begin{aligned}
& \text { Reaction } \mathrm{A}^{\prime \prime}+\mathrm{B}: 1-X^{1 / 3} \\
& \quad=1-\left[\alpha_{\mathrm{A}^{\prime \prime}}\left(1-k_{\mathrm{A}^{\prime \prime}} t\right)^{3}+\alpha_{\mathrm{B}}\left(1-k_{\mathrm{B}} t\right)^{3}+\alpha_{\mathrm{C}}\right]^{1 / 3}
\end{aligned}
$$

Reaction B: $1-X^{1 / 3}=1-\left[\alpha_{\mathrm{B}}\left(1-k_{\mathrm{B}} t\right)^{3}+\alpha_{\mathrm{C}}\right]^{1 / 3}$

$$
\begin{aligned}
& \text { Reaction B + C:1- } X^{1 / 3} \\
& \quad=1-\left[\alpha_{\mathrm{B}}\left(1-k_{\mathrm{B}} t\right)^{3}+\alpha_{\mathrm{C}}\left(1-k_{\mathrm{C}}\left(t-t_{0}\right)\right)^{3}\right]^{1 / 3}
\end{aligned}
$$

Reaction C: $1-X^{1 / 3}=1-\left[\alpha_{\mathrm{C}}\left(1-k_{\mathrm{C}}\left(t-t_{0}\right)\right)^{3}\right]^{1 / 3}$

Experimental data of the relative penetration and previous relationships enabled us to calculate the reaction constants of each reaction $k_{i}$ (see Figure $7 \mathrm{c}$ and Table 3 ).

Discussion. A complex reduction behavior of $\mathrm{La}_{2} \mathrm{Mo}_{2} \mathrm{O}_{9}$ is observed. Depending on the temperature and on the specific surface area of particles, different reactions are occurring with different kinetics. According to the fitted models, the kinetic constant of the amorphous phase reduction (reaction B) seems to vary with sample, which is not clearly visible in the derivative of the thermogravimetric data. The kinetic law used in this work is based on the hypothesis that (i) the particles are spherical and (ii) the influence of diffusion and nucleation are negligible 
because the flow rate used is supposed to be large enough to not interfere with the reduction mechanism. Since it might not be strictly the case for all samples, one has to keep in mind that some approximation or interpretation errors can occur in our analyses.

Nevertheless, as expected, reduction kinetics is influenced by the microstructure of the particles. Higher specific surface areas induce a larger solid/gas interface which improves diffusion of hydrogen and of oxide ions at the grains surface. The same observation was reported in a study by Goel et al. on dense and porous pellets, in which higher reduction was obtained for higher porosity fraction. ${ }^{24}$ Moreover, since $\mathrm{H}_{2} \mathrm{O}$ is formed during reduction, the diffusion of oxide ions on the grain surface could be influenced by the presence of water vapor. In fact, it was found that the oxygen surface exchange process in $\mathrm{La}_{2} \mathrm{Mo}_{2} \mathrm{O}_{9}$ is improved for a wet exchange $\left(\mathrm{H}_{2}{ }^{18} \mathrm{O} /{ }^{16} \mathrm{O}\right) \cdot{ }^{25,26}$ In this case, $\mathrm{H}_{2} \mathrm{O}$ formed during reduction could play a role in the reduction mechanism. Using another reductive gas, Jacquens et al. reported that LAMOX samples are stable when annealed in dry propane:air mixture, while they get reduced in wet propane:air mixture. ${ }^{27}$ One can therefore suppose that the water vapor formed could accelerate reduction, despite the fact that $\mathrm{pO}_{2}$ increases with $\mathrm{pH}_{2} \mathrm{O}$. In addition, for particles with higher specific surface area, the higher reduction rate could be due to the higher surface exchange of oxygen, hence more important formation of $\mathrm{H}_{2} \mathrm{O}$.

No matter the cause, in all cases, temperature or specific surface area, the reduction of $\mathrm{La}_{2} \mathrm{Mo}_{2} \mathrm{O}_{9}$ leads to the amorphous phase $\mathrm{La}_{2} \mathrm{Mo}_{2} \mathrm{O}_{7-y}$ and for severe reduction to exsolution of metallic molybdenum. In the literature, the exsolution of metallic nanoparticles such as $\mathrm{Ni}$ dissolved as an oxide by cationic substitution into the compound and precipitated under reductive atmosphere after heating has been reported in nonstoichiometric perovskites, ${ }^{28}$ and it was shown to increase the electrocatalytic properties. $^{29,30}$ In the same way, the presence of metallic molybdenum could enhance the electronic and catalytic properties of the materials. However, the decomposition into metallic molybdenum suggests that amorphous phase $\mathrm{La}_{2} \mathrm{Mo}_{2} \mathrm{O}_{7-y}$ is not thermodynamically stable under reductive atmosphere, as already mentioned by Vega-Castillo et al. ${ }^{10}$ Indeed, the reduction kinetics under diluted $\mathrm{H}_{2}$ is very slow (Figures 2 and 4) but does not show any stabilization of the oxygen content of the amorphous phase: according to the model, the kinetic constant of Reaction $\mathrm{C}$ is very weak, and a correlatively very long reduction time would lead to full decomposition into metallic Mo. Definitely no thermodynamic equilibrium is reached for the amorphous phase.

The slow evolution of the metallic Mo weight fraction is also noticed in the quantitative analysis of the amorphous phase and metallic Mo through XRD (Table 2). Figure 8 shows XRD data recorded for powders synthesized with DEG and reduced for 34 and $60 \mathrm{~h}$.

The average oxygen content of the latter is 5.09, and no quantitative Rietveld analysis was possible because of the small quantity of powder. However, the integration of the molybdenum peak at $2 \theta=41^{\circ}$ in comparison with the other samples suggests an extrapolation to $1.5 \mathrm{wt} \%$ of metallic molybdenum. Nevertheless, the XRD pattern recorded on this sample reduced for $60 \mathrm{~h}$ shows at $2 \theta=22^{\circ}$ an abnormally large hump of the amorphous phase (see arrow in Figure 8). Comparatively, the corresponding hump in the XRD pattern of the sample reduced for $34 \mathrm{~h}$ is narrower. It suggests either that amorphous $\mathrm{La}_{2} \mathrm{Mo}_{2} \mathrm{O}_{7-y}$ can accept a certain substoichiometry in molybdenum or that a second amorphous phase with higher

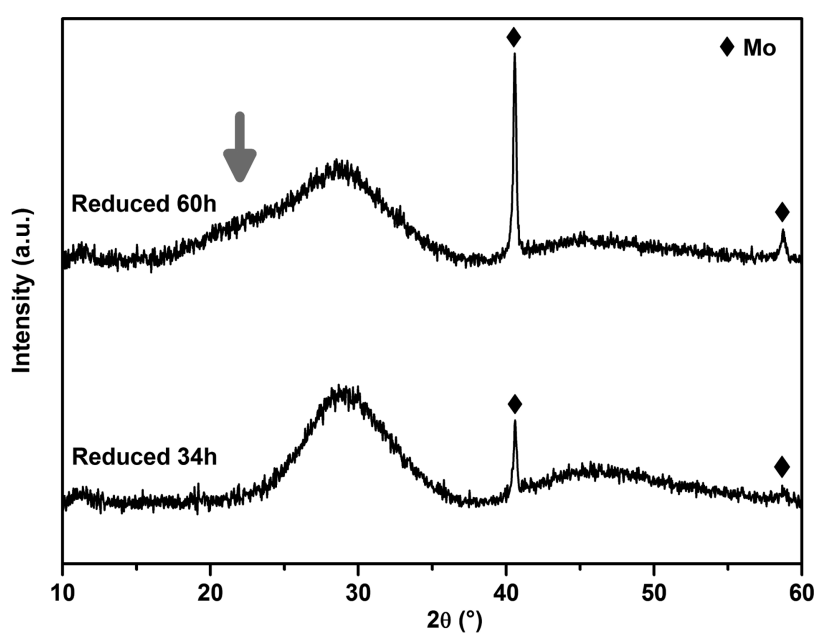

Figure 8. XRD patterns of the reduced DEG sample after 34 and $60 \mathrm{~h}$. Note the low angle distortion in the first amorphous hump of the sample reduced at $60 \mathrm{~h}$ (see arrow and comment in the text) compared to the other.

lanthanum content is formed when Mo exsolution becomes important. In the $\mathrm{La}_{2} \mathrm{O}_{3}-\mathrm{MoO}_{3}$ phase diagram, the closest composition in the molybdenum-deficient side is $\mathrm{La}_{2} \mathrm{MoO}_{6}{ }^{31}$ which is often observed when the molybdenum of $\mathrm{La}_{2} \mathrm{Mo}_{2} \mathrm{O}_{9}$ reacts with an alkaline element. ${ }^{32}$ This compound can get reduced to $\mathrm{La}_{2} \mathrm{MoO}_{5}$, and its main diffraction peak lies close to the extra hump observed in the XRD pattern. However, if this extra hump was due to an amorphized reduced phase of this type, its amount would be no more than a few percent, hence hardly visible in the diffraction pattern. We therefore consider that the most likely is an extension of the amorphous range to La:Mo > 1 stoichiometry. In any case, these results seem to confirm the instability of the amorphous phase $\mathrm{La}_{2} \mathrm{Mo}_{2} \mathrm{O}_{7-y}$ in a reductive atmosphere. However, when amorphous $\mathrm{La}_{2} \mathrm{Mo}_{2} \mathrm{O}_{7-y}$ was tested as anode in a SOFC device, negligible losses in electrical properties were observed for over 4 days ${ }^{11}$ and even for over 30 days. ${ }^{13}$ This suggests that the amorphous phase was stable under the reducing atmosphere of a SOFC in operating conditions. Determinant effects as anodic overpotential, oxide ion migration from the electrolyte, or water vapor emission during fuel cell operation might lead to stabilization of the amorphous phase.

Reoxidation of the Reduced $\mathrm{La}_{2} \mathrm{Mo}_{2} \mathrm{O}_{7-y}$ Amorphous Phase. The reoxidation of a LAMOX material was already used in order to estimate the oxygen loss after reduction. ${ }^{6}$ It is faster than the reduction. However, the phase evolution during reoxidation of the amorphous reduced phase $\mathrm{La}_{2} \mathrm{Mo}_{2} \mathrm{O}_{7-y}$ had never been described. The thermogravimetric and DTA measurements were performed in air on two reduced samples (SSR and DEG) and are presented in Figure 9.

Beforehand, both initial $\mathrm{La}_{2} \mathrm{Mo}_{2} \mathrm{O}_{9}$ powders were reduced to the amorphous phase in TG apparatus at $700{ }^{\circ} \mathrm{C}$ under $10 \% \mathrm{H}_{2}$ / Ar and a flow rate of $4.8 \mathrm{~L} \cdot \mathrm{h}^{-1}$, resulting in compounds with an approximate oxygen content of 6.7 (corresponding to a mass loss of $6.1 \%$ ). The thermogravimetric curves of reoxidation, recorded upon heating up to $700{ }^{\circ} \mathrm{C}$ at $10^{\circ} \mathrm{C} \cdot \mathrm{min}^{-1}$ in flowing air $(6 \mathrm{~L}$. $\left.\mathrm{h}^{-1}\right)$ and then cooling down, show a reoxidation depending on the specific surface area of the initial compounds: the reduced DEG sample starts to reoxidize around $200{ }^{\circ} \mathrm{C}$, whereas the reduced SSR sample starts to reoxidize around $350{ }^{\circ} \mathrm{C}$ (Figure 9a). After a complete cycle the mass gains suggest complete reoxidation. In the same way, DTA measurements present a 

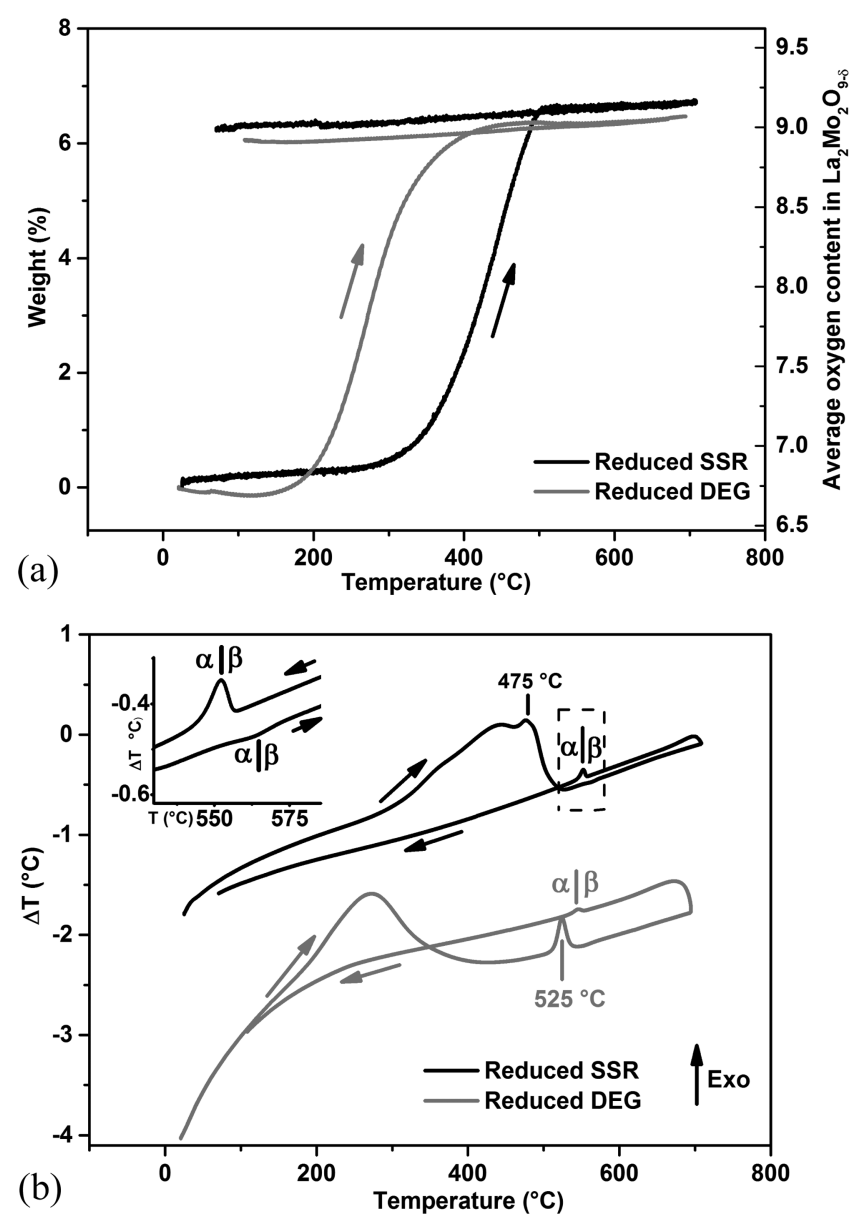

Figure 9. Thermal behavior during reoxidation of the reduced SSR and DEG samples: (a) thermogravimetric measurements; (b) DTA measurements, (inset) $\alpha / \beta \mathrm{La}_{2} \mathrm{Mo}_{2} \mathrm{O}_{9}$ transition of the SSR sample.

comparable thermal history with an exothermic transfer hump corresponding to reoxidation of the material, in agreement with the mass gain (Figure $9 \mathrm{~b}$ ). At $475^{\circ} \mathrm{C}$ for the reduced SSR sample and $525^{\circ} \mathrm{C}$ for the reduced DEG, the samples show a second exothermic peak. XRD patterns recorded below this exothermic peak's temperature show a purely amorphous phase, whereas above this temperature crystalline $\mathrm{La}_{2} \mathrm{Mo}_{2} \mathrm{O}_{9}$ appears. It indicates that these exothermic signals correspond to crystallization peaks. The thermal behaviors around $560^{\circ} \mathrm{C}$ (see inset) match up with the structural $\alpha / \beta$ phase transition of $\mathrm{La}_{2} \mathrm{Mo}_{2} \mathrm{O}_{9}$ on the DTA measurements. ${ }^{5}$

In order to observe the reoxidation kinetics of the amorphous phase, thermogravimetric measurements in air at $350^{\circ} \mathrm{C}$ for $60 \mathrm{~h}$ were performed on the amorphous $\mathrm{La}_{2} \mathrm{Mo}_{2} \mathrm{O}_{6.66}$ compound, obtained from SSR synthesis followed by reduction in TG apparatus at $700{ }^{\circ} \mathrm{C}$ (Figure 10). The mass gain is faster during the first hours than later on. In this condition, after $12 \mathrm{~h}$ of reoxidation the sample is still amorphous, and after $60 \mathrm{~h}$ (see inserted box on the Figure 10), a weak reflection appears at $2 \theta=$ $28^{\circ}$, corresponding to the most intense peak of $\mathrm{La}_{2} \mathrm{Mo}_{2} \mathrm{O}_{9}$. Note that after $60 \mathrm{~h}$ the sample is still gaining weight, indicating that thermodynamic equilibrium has not been reached yet. Regarding to the mass gains measured after cooling down to room temperature, the stoichiometries corresponding to 12 and $60 \mathrm{~h}$ of reoxidation are, respectively, $\mathrm{La}_{2} \mathrm{Mo}_{2} \mathrm{O}_{8.81}$ and $\mathrm{La}_{2} \mathrm{Mo}_{2} \mathrm{O}_{8.85}$. The $12 \mathrm{~h}$ reoxidized powder presents a dark brown color, whereas after $60 \mathrm{~h}$ it presents a light brown/orange color. The same

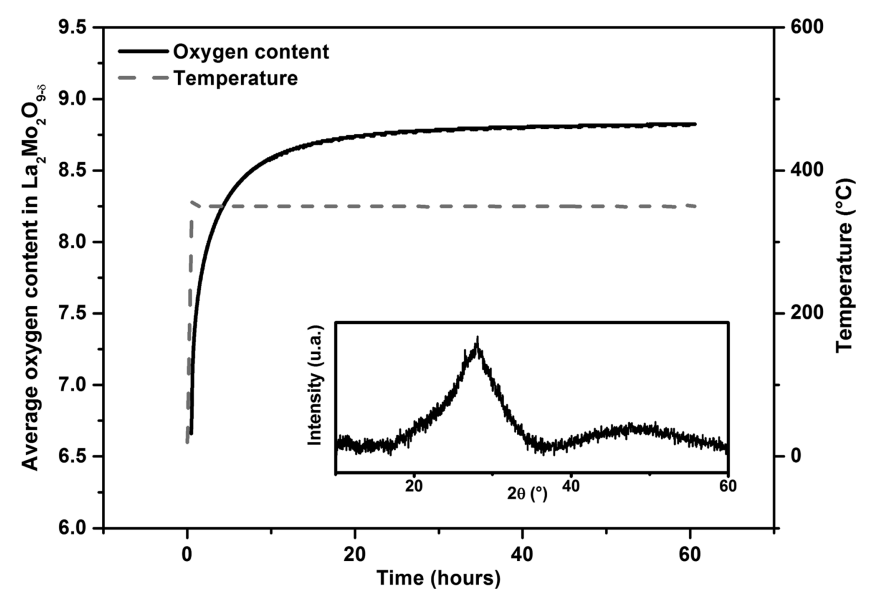

Figure 10. Thermogravimetric measurement during reoxidation of the $\mathrm{La}_{2} \mathrm{Mo}_{2} \mathrm{O}_{6.66}$ SSR sample at $350^{\circ} \mathrm{C}$; (insert) XRD pattern after $60 \mathrm{~h}$ of reoxidation.

mathematic model as used previously for the reduction did not enable us to fit correctly the reoxidation kinetics (may be because of oxygen diffusion).

The same types of experiments were also performed in a muffle furnace. A reduced SSR sample was heated up by placing the powder directly in a preheated furnace at different constant temperatures during different annealing times (see Figure 11a, for the RT DRX patterns after cooling down). As mentioned previously, the reoxidized compounds keep their amorphous structure after $12 \mathrm{~h}$ and even after 4 weeks at $350{ }^{\circ} \mathrm{C}$. For a temperature of $400{ }^{\circ} \mathrm{C}$, after $1 \mathrm{~h}$, the structure remains mostly amorphous, with a weak reflection at $2 \theta=28^{\circ}$ on the XRD pattern. However, at higher temperature it recrystallizes (only a slight undulation of the background is detected in the compound reoxidized at $450{ }^{\circ} \mathrm{C}$ ). A similar behavior is observed for reoxidation of sample obtained by DEG (Figure 11b) in muffle furnace in the same conditions. However, recrystallization of this sample occurs at much lower temperature than with sample obtained by SSR, which is consistent with the specific surface areas.

After $12 \mathrm{~h}$ of annealing in air at $100{ }^{\circ} \mathrm{C}$, the DEG compound remains amorphous. At higher temperature, mixtures of amorphous and crystalline phases are observed (as, for instance, after $12 \mathrm{~h}$ at $150{ }^{\circ} \mathrm{C}$, see Figure $11 \mathrm{~b}$ ). At $500{ }^{\circ} \mathrm{C}$ after $1 \mathrm{~h}$, the compound appears totally (or at least largely) crystallized as $\mathrm{La}_{2} \mathrm{Mo}_{2} \mathrm{O}_{9}$ with a mean crystallite size of $53 \mathrm{~nm}$ compared to the initial powder of $41 \mathrm{~nm}$ (as estimated from XRD peaks fwhm after deduction of apparatus contribution, according to the Scherrer equation). After annealing, the powders of all these samples do not present a homogeneous color: a brown color matrix with few white dots, while white phase content increases with annealing temperature (confirming that thermodynamic equilibrium has not been reached in any of these samples). We can also notice a difference on the crystallization temperature between DTA and muffle furnace, due to a thermal dynamic regime with air flow in DTA compared to the static regime in muffle furnace.

As for the reduction, higher gas/ceramic contact surface is related to faster oxidation kinetics. Also, these results show that the molybdenum cations, into the amorphous phase, accept a large variety of oxidation states and mixed valences. It results in a complex valence continuum during reoxidation. For instance, the $\mathrm{La}_{2} \mathrm{Mo}_{2} \mathrm{O}_{6.66}$ compound, where molybdenum has an average 

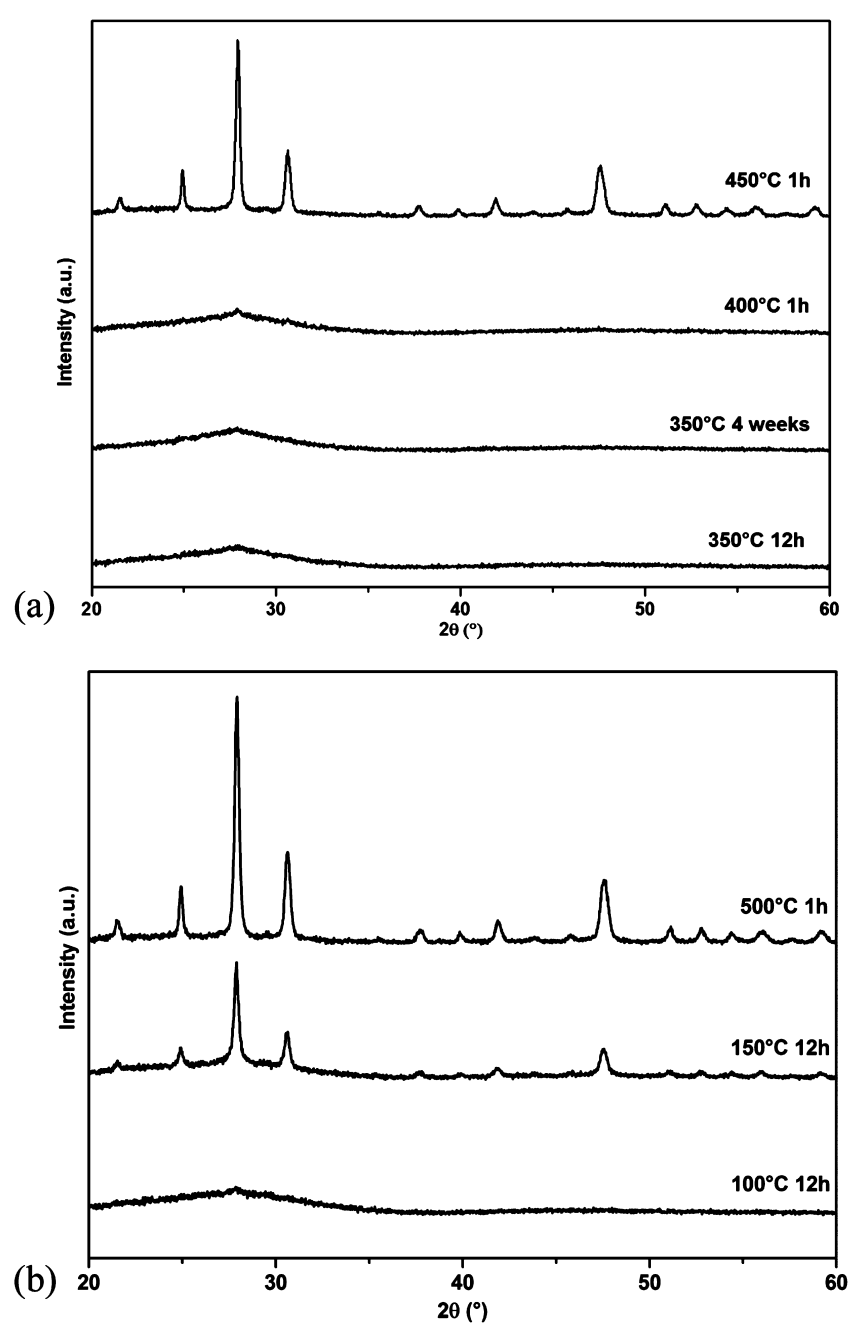

Figure 11. XRD patterns after reoxidation in a muffle furnace for different annealing times at different temperatures of reduced SSR (a) and DEG (b) samples.

oxidation state of +3.66 , presents, after $60 \mathrm{~h}$ of reoxidation at 350 ${ }^{\circ} \mathrm{C}$, an Mo oxidation state of approximately +5.85 . The amorphous phase allows a versatile oxygen composition. The powders of amorphous reoxidized compounds exhibit different colors compared to the other crystallized phases such as $\mathrm{La}_{2} \mathrm{Mo}_{2} \mathrm{O}_{9}$ (creamy white), $\mathrm{La}_{2} \mathrm{Mo}_{2} \mathrm{O}_{8.96}$ (light gray), ${ }^{10}$ $\mathrm{La}_{7} \mathrm{Mo}_{7} \mathrm{O}_{30}$ (black), ${ }^{7}$ and even to amorphous $\mathrm{La}_{2} \mathrm{Mo}_{2} \mathrm{O}_{7-y}$ (also black), which suggests unusual valences and environments of molybdenum ions. Moreover, as described previously in a previous section, the amorphous phase could also accept a substoichiometry in molybdenum. This should imply different electrical properties of the amorphous phase depending on its composition in oxygen and molybdenum.

\section{CONCLUSIONS}

In this work, the reduction kinetics of $\mathrm{La}_{2} \mathrm{Mo}_{2} \mathrm{O}_{9}$ was studied at 700 and $760{ }^{\circ} \mathrm{C}$ by thermogravimetric analysis of powders with different specific surface areas. The phase evolution during

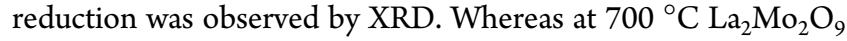
reduced directly into the amorphous phase $\mathrm{La}_{2} \mathrm{Mo}_{2} \mathrm{O}_{7-y}$, at 760 ${ }^{\circ} \mathrm{C}$ the $\mathrm{La}_{7} \mathrm{Mo}_{7} \mathrm{O}_{30}$ intermediate phase of reduction is present before amorphization. In both cases, severe reduction leads to an exsolution of metallic molybdenum favored by a high specific surface area. The study of the reduction kinetics shows mainly two mechanisms. The first one, associated with the reduction of $\mathrm{La}_{2} \mathrm{Mo}_{2} \mathrm{O}_{9}$ to amorphous $\mathrm{La}_{2} \mathrm{Mo}_{2} \mathrm{O}_{7}$, is faster than the second one, corresponding to the reduction of amorphous $\mathrm{La}_{2} \mathrm{Mo}_{2} \mathrm{O}_{7}$. None of these experiments left trace amounts of crystallized $\mathrm{La}_{2} \mathrm{Mo}_{2} \mathrm{O}_{7} \cdot{ }^{33}$

The exsolution of metallic molybdenum is an interesting feature. It could improve the electrocatalytic properties of the materials. Anyway, it shows that the amorphous phase is not in a thermodynamically stable state. The operating conditions of a SOFC fuel cell could however be responsible for its stabilization.

Finally, we reported here for the first time the ability of the amorphous phase to get highly reoxidized in air at low temperature while keeping its amorphous structure, thus enlarging its ranges of mixed Mo oxidation states and ionicelectronic conductivity properties. This is a significant result, especially when considering the presumed role of such type of slightly reduced amorphous phase in the huge increase of conductivity recently measured in $\mathrm{La}_{2} \mathrm{Mo}_{2} \mathrm{O}_{9}$ nanowires. ${ }^{14}$

\section{AUTHOR INFORMATION}

\section{Corresponding Author}

*E-mail: philippe.lacorre@univ-lemans.fr.

\section{Notes}

The authors declare no competing financial interest.

\section{ACKNOWLEDGMENTS}

The authors acknowledge Region Pays de la Loire for financial support (PERLE2 project, convention no. 2010 10302) and Pr. François Goutenoire for the helpful discussion concerning quantitative Rietveld analyses.

\section{REFERENCES}

(1) Cowin, P. I.; Petit, C. T. G.; Lan, R.; Irvine, J. T. S.; Tao, S. Adv. En. Mater. 2011, 1, 314-332.

(2) Park, S. D.; Vohs, J. M.; Gorte, R. J. Nature 2000, 404, 265-267.

(3) Gong, M.; Liu, X.; Trembly, J.; Johnson, C. J. Power Sources 2007, 168, 289-298.

(4) Lacorre, P.; Goutenoire, F.; Bohnke, O.; Retoux, R.; Laligant, Y. Nature 2000, 404, 856-858.

(5) Georges, S.; Goutenoire, F.; Laligant, Y.; Lacorre, P. J. Mater. Chem. 2003, 13, 2317-2321.

(6) Marrero-Lopez, D.; Canales-Vazquez, J.; Ruiz-Morales, J. C.; Irvine, J. T. S.; Nunez, P. Electrochim. Acta 2005, 50, 4385-4395.

(7) Goutenoire, F.; Retoux, R.; Suard, E.; Lacorre, P. J. Solid State Chem. 1999, 142, 228-235.

(8) Vega-Castillo, J.; Mogni, L.; Corbel, G.; Lacorre, P.; Caneiro, A. Int. J. Hydrogen Energy 2010, 35, 5890-5894.

(9) Vega-Castillo, J. E.; Ravella, U. K.; Corbel, G.; Lacorre, P.; Caneiro, A. Dalton Trans. 2014, 43, 2661-2669.

(10) Vega-Castillo, J. E.; Ravella, U. K.; Corbel, G.; Lacorre, P.; Caneiro, A. Dalton Trans. 2012, 41, 7266-7271.

(11) Lu, X. C.; Zhu, J. H. J. Electrochem. Soc. 2008, 155, B1053-B1057.

(12) Yao, C. C.; Tsai, D. S.; Lo, J. C.; Chung, W. H.; Wilkinson, D. P. Int. J. Hydrogen Energy 2012, 37, 9792-9800.

(13) Buvat, G.; Quarez, E.; Joubert, O. J. Power Sources 2016, 302, 107-113.

(14) Liu, W.; Pan, W.; Luo, J.; Godfrey, A.; Ou, G.; Wu, H.; Zhang, W. Nat. Commun. 2015, 6, 8354.

(15) Ravella, U. K. Ph.D. Thesis, Université du Maine, France, 2012.

(16) Vega-Castillo, J. E. Ph.D. Thesis, Centro Atómico Bariloche, Argentina, 2013.

(17) Sellemi, H. Ph.D. Thesis, Université du Maine, France, 2014.

(18) Sellemi, H.; Coste, S.; Barre, M.; Retoux, R.; Ben Ali, A.; Lacorre, P. J. Alloys Compd. 2015, 653, 422-433. 
(19) Sellemi, H.; Coste, S.; Ben Ali, A.; Retoux, R.; Smiri, L. S.; Lacorre, P. Ceram. Int. 2013, 39, 8853-8859.

(20) Bessières, J. Ph.D. Thesis, Université de Metz, France, 1983.

(21) Bessieres, J.; Bessieres, A.; Heizmann, J. J. Int. J. Hydrogen Energy 1980, 5, 585-595.

(22) Haber, J. J. Less-Common Met. 1977, 54, 243-261.

(23) Sloczynski, J.; Bobinski, W. J. Solid State Chem. 1991, 92, 420435.

(24) Goel, M.; Djurado, E.; Georges, S. Solid State Ionics 2011, 204205, 97-103.

(25) Georges, S.; Skinner, S. J.; Lacorre, P.; Steil, M. C. Dalton Trans. 2004, 3101-3105.

(26) Liu, J.; Chater, R. J.; Morris, R. J. H.; Skinner, S. J. Solid State Ionics 2011, 189, 39-44.

(27) Jacquens, J.; Farrusseng, D.; Georges, S.; Viricelle, J. P.; Gaudillere, C.; Corbel, G.; Lacorre, P. Fuel Cells 2010, 10, 433-439.

(28) Neagu, D.; Tsekouras, G.; Miller, D. N.; Menard, H.; Irvine, J. T. S. Nat. Chem. 2013, 5, 916-923.

(29) Caldes, M. T.; Kravchyk, K. V.; Benamira, M.; Besnard, N.; Gunes, V.; Bohnke, O.; Joubert, O. Chem. Mater. 2012, 24, 4641-4646.

(30) Madsen, B. D.; Kobsiriphat, W.; Wang, Y.; Marks, L. D.; Barnett, S. ECS Trans. 2007, 7, 1339-1348.

(31) Fournier, J. P.; Fournier, J.; Kohlmuller, R. Bull. Soc. Chim. Fr. 1970, 12, 4277-4283.

(32) Corbel, G.; Mestiri, S.; Lacorre, P. Solid State Sci. 2005, 7, 12161224.

(33) Moini, A.; Subramanian, M. A.; Clearfield, A.; Disalvo, F. J.; McCarroll, W. H. J. Solid State Chem. 1987, 66, 136-143. 